Article

\title{
Morphological and Molecular Characterization of Five Species Including Three New Species of Golden Gorgonians (Cnidaria: Octocorallia) from Seamounts in the Western Pacific
}

\author{
Yu Xu ${ }^{1,2,3,+}$, Zifeng Zhan ${ }^{1,+}$ (D) and Kuidong $X u^{1,2,3, *}$ \\ 1 Laboratory of Marine Organism Taxonomy and Phylogeny, Shandong Province Key Laboratory of \\ Experimental Marine Biology, Center for Ocean Mega-Science, Institute of Oceanology, \\ Chinese Academy of Sciences, Qingdao 266071, China; xuyu16@mails.ucas.ac.cn (Y.X.); \\ zzhan@qdio.ac.cn (Z.Z.) \\ 2 Southern Marine Science and Engineering Guangdong Laboratory (Zhuhai), Zhuhai 519082, China \\ 3 University of Chinese Academy of Sciences, Beijing 100049, China \\ * Correspondence: kxu@qdio.ac.cn; Tel.: +86-0532-8289-8776 \\ + Contributed equally to this work.
}

check for updates

Citation: Xu, Y.; Zhan, Z.; Xu, K. Morphological and Molecular Characterization of Five Species Including Three New Species of Golden Gorgonians (Cnidaria:

Octocorallia) from Seamounts in the Western Pacific. Biology 2021, 10, 588. https://doi.org/10.3390/

biology10070588

Academic Editor: Alberto

Teodorico Correia

Received: 29 April 2021

Accepted: 24 June 2021

Published: 26 June 2021

Publisher's Note: MDPI stays neutral with regard to jurisdictional claims in published maps and institutional affiliations.

Copyright: (c) 2021 by the authors. Licensee MDPI, Basel, Switzerland. This article is an open access article distributed under the terms and conditions of the Creative Commons Attribution (CC BY) license (https:/ / creativecommons.org/licenses/by/ $4.0 /)$.
Simple Summary: Deep-water octocorals are main components of vulnerable marine ecosystems (VMEs) and play an important role in conservation and research. Iridogorgia Verill, 1883 is a distinct octocoral group characterized by a remarkably spiral structure and large size in deep sea, where the diversity of Iridogorgia is poorly known in the Western Pacific. Based on the collection of Iridogorgia specimens from seamounts in the tropical Western Pacific, we described five species including three new species using an integrated morphological-molecular approach. We assessed the potential of the mitochondrial genes MutS and COI, and the nuclear 28S rDNA for species delimitation and phylogenetic reconstruction of Iridogorgia. The results suggest that the mitochondrial markers are not able to resolve the species boundaries and deeply divergent relationships adequately, while $28 \mathrm{~S}$ rDNA showed potential application in DNA barcoding and phylogenetic reconstruction for this genus. This study will help to understand the Iridogorgia biodiversity in the Western Pacific and shed more light on the screening of barcodes for octocorals.

Abstract: Members of genus Iridogorgia Verrill, 1883 are the typical deep-sea megabenthos with only seven species reported. Based on an integrated morphological-molecular approach, eight sampled specimens of Iridogorgia from seamounts in the tropical Western Pacific are identified as three new species, and two known species I. magnispiralis Watling, 2007 and I. densispicula Xu, Zhan, Li and $\mathrm{Xu}, 2020$. Iridogorgia flexilis sp. nov. is unique in having a very broad polyp body base with stout and thick scales. Iridogorgia densispiralis sp. nov. can be distinguished by rods present in both polyps and coenenchyme, and I. verrucosa sp. nov. is characterized by having numerous verrucae in coenenchyme and irregular spindles and scales in the polyp body wall. Phylogenetic analysis based on the nuclear $28 \mathrm{~S}$ rDNA indicated that I. densispiralis sp. nov. showed close relationships with I. splendens Watling, 2007 and I. verrucosa sp. nov., and I. flexilis sp. nov. formed a sister clade with I. magnispiralis. In addition, due to Rhodaniridogorgia fragilis Watling, 2007 nested into the Iridogorgia clade in mtMutS-COI trees and shared highly similar morphology to the latter, we propose to eliminate the genus Rhodaniridogorgia by establishing a new combination Iridogorgia fragilis (Watling, 2007) comb. nov. and resurrecting I. superba Nutting, 1908.

Keywords: Anthozoa; Chrysogorgiidae; Iridogorgia flexilis; Iridogorgia verrucosa; Iridogorgia densispiralis; taxonomy; morphology; phylogeny

\section{Introduction}

Deep-water octocorals are main components of vulnerable marine ecosystems (VMEs) and represent one group of VME-indicator species, playing an important role in conser- 
vation and research [1,2]. The octocorals usually have slow growth rates and long life, which suggest that full recovery from damage can take from decades to centuries, depending on the species [3]. The genus Iridogorgia is an easily recognized octocoral group which is characterized by a remarkably spiral structure and large size at water depths of 558-2311 m [4-7]. The species Iridogorgia magnispiralis Watling, 2007 is a representative, which is known as the world's largest gorgonian reaching about $5.7 \mathrm{~m}$ tall [8].

Currently, only seven valid species are known in the genus Iridogorgia [7,9]. Among them, four species are found in the North Atlantic, especially on the seamounts of the Northwest Atlantic, including I. pourtalesii Verrill, 1883, I. magnispiralis Watling, 2007, I. splendens Watling, 2007 and I. fontinalis Watling, 2007 [4,10,11]. Two species are recorded off the coast of Hawaii: I. bella Nutting, 1908 and I. magnispiralis $[4,8,11-13]$. The diversity of Iridogorgia in the Western Pacific is still poorly known, I. magnispiralis was found in the Phoenix area and Northeast Australia [6,14], and I. densispicula Xu, Zhan, Li and Xu, 2020 and I. squarrosa $\mathrm{Xu}, \mathrm{Zhan}, \mathrm{Li}$ and $\mathrm{Xu}, 2020$ are found in the seamounts near the Mariana Trench [7].

While studying the seamount benthic diversity in the tropical Western Pacific Ocean, we collected eight specimens of Iridogorgia from the seamounts located on the Caroline Ridge in 2019. Based on the integrated morphological-molecular approach, we described three new species including Iridogorgia flexilis sp. nov., I. verrucosa sp. nov. and I. densispiralis sp. nov., and reported two known species I. magnispiralis and I. densispicula. Meanwhile, we assessed the potential of the genetic distance of the mitochondrial genes MutS and COI, and the nuclear $28 \mathrm{~S}$ rDNA for species discrimination of this genus. We also compared the resolving power of the mitochondrial and nuclear markers for the phylogenetic reconstruction. The objective of this study was to help understand the Iridogorgia diversity in the Western Pacific and shed more light on the screening of barcodes for the octocorals.

\section{Materials and Methods}

\subsection{Specimen Collection and Morphological Examination}

Eight specimens were obtained from the seamounts located on the Caroline Ridge by ROV FaXian (Discovery) in the tropical Western Pacific in 2019. These specimens were photographed in situ before being sampled, photographed on board, and then stored in $75 \%$ ethanol after collection. A few branches were stored at $-80{ }^{\circ} \mathrm{C}$ for molecular research. Their morphology and anatomy were examined by using a stereo dissecting microscope. The preparation of sclerites for imaging follows Xu et al. (2020) [7]. SEM scans were obtained and the optimum magnification was chosen for each kind of polyps and sclerites by using TM3030Plus SEM. The morphological terminology used follows Bayer et al. (1983) [15].

The type specimen of the three new species has been deposited in the Marine Biological Museum of Chinese Academy of Sciences (MBMCAS) Qingdao, China. The three new species have been registered in ZooBank.

\subsection{DNA Extraction and Sequencing}

Genomic DNA was extracted by a DNeasy Blood and Tissue Kit (Qiagen, Hilden, Germany) following the instructions. The mitochondrial regions of mutS homolog (mtMutS) and cytochrome oxidase subunit I (COI) and an approximately 800-nt fragment of the $28 \mathrm{~S}$ nuclear ribosomal gene ( $28 \mathrm{~S} \mathrm{rDNA}$ ) were selected for the phylogenetic analysis. To amplify mtMutS and COI, the primer pairs AnthoCorMSH (5'-AGGAGAATTATTCTAAGTATGG$\left.3^{\prime}\right)$ [16] and Mut-3458R (5'-TSGAGCAAAAGCCACTCC-3') [17], COI8414-F (5'-CCAGGTAGTATGTTAGGRGA-3'; McFadden, unpublished) and HCO2198 (5' - TAAACTTCAGGGTGACCAAAAAATCA-3 ${ }^{\prime}$ ) [18] were used, respectively. PCR reactions were conducted with the following conditions: $2 \mathrm{~min}$ at $98{ }^{\circ} \mathrm{C}$ followed by 35 cycles $\left(98^{\circ} \mathrm{C}\right.$ for $15 \mathrm{~s}, 45-50{ }^{\circ} \mathrm{C}$ for $15 \mathrm{~s}$, and $72{ }^{\circ} \mathrm{C}$ for $60 \mathrm{~s}$ ) and a final extension at $72{ }^{\circ} \mathrm{C}$ for $2 \mathrm{~min}$. We sequenced $28 \mathrm{~S}$ rDNA using primers 28S-Far (5'-CACGAGACCGATAGCGAACAAGTA-3') and 28SRar (5'-TCATTTCGACCCTAAGACCTC- $\left.3^{\prime}\right)$ [19], and the same PCR protocol used for 
mtMutS. PCR reactions were performed using I- $5^{\mathrm{TM}} 2 \times$ High-Fidelity Master Mix DNA polymerase, and sequencing was performed by TsingKe Biological Technology (TsingKe Biotech, Beijing, China).

\subsection{Genetic Distance and Phylogenetic Analyses}

All the Iridogorgia sequences and the related chrysogorgiid genera and out-group species Plexaura kuna were downloaded from GenBank (Table 1). The sequences were aligned using MAFFT v.7 [20] with the G-INS-i and Q-INS-i algorithms for the mitochondrial and $28 \mathrm{~S}$ rDNA regions, respectively. The nucleotide alignment was trimmed to equal length using BioEdit v7.0.5 [21]. The COI alignment showed that Iridogorgia magnispiralis DQ860111 and I. splendens DQ860112 shared few overlap positions ( $<100 \mathrm{bp})$ with the other Iridogorgia sequences, and therefore these two sequences were excluded from the analysis. Genetic distances of single loci and the concatenated region mtMutS-28S between species/populations were calculated with MEGA 6.0 using Kimura 2-parameter model [22].

Phylogenetic analyses were performed on $28 \mathrm{~S}$ rDNA and the concatenated mtMutSCOI. For the phylogenetic construction, when conspecific sequences showed no genetic variation, one was chosen randomly for analysis. Model selection and Maximum likelihood (ML) analyses were carried out using PhyML (ver. 3.0, see http:/ / www.atgc-montpellier. $\mathrm{fr} / \mathrm{phyml} /($ accessed on 28 April 2021); [23]) on the online ATGC bioinformatic platform. The best-fitted model GTR + G was selected with the Akaike information criterion for both the mitochondrial and 28S rDNA alignments. Node support for the ML trees came from a majority-rule consensus tree of 1000 bootstrap replicates. Following Hillis and Bull (1993) [24], the ML bootstraps $<70 \%, 70-94 \%$ and $\geq 95 \%$ were considered as low, moderate and high, respectively. Bayesian inference (BI) analysis was carried out using MrBayes v3.2.7a [25]. Posterior probability was estimated based on 10,000,000 Monte Carlo Markov Chain $(\mathrm{MCMC})$ generations $(\times 4$ chains) sampling every 1000 generations (burn-in $=25 \%$ ). Convergence of the MCMC was assessed using Tracer 1.4.1 [26]. Following Alfaro et al. (2003) [27], the Bayesian posterior probabilities $<0.95$ and $\geq 0.95$ were considered as low and high, respectively.

Table 1. The sequences used in this study.

\begin{tabular}{|c|c|c|c|c|c|c|}
\hline \multirow{2}{*}{ Species } & \multirow{2}{*}{ Voucher Number } & \multirow{2}{*}{ Locatiom } & \multirow{2}{*}{ References } & \multicolumn{3}{|c|}{ GenBank Accession Numbers } \\
\hline & & & & mtMutS & COI & $28 S$ rDNA \\
\hline Iridogorgia densispiralis sp. nov. & MBM286454 & $10.37^{\circ} \mathrm{N}, 140.30^{\circ} \mathrm{E}$ & present study & MW841033 & MW841036 & MW841043 \\
\hline Iridogorgia flexilis sp. nov. & MBM286453 & $10.40^{\circ} \mathrm{N}, 140.90^{\circ} \mathrm{E}$ & present study & MW841031 & MW841035 & MW841041 \\
\hline Iridogorgia verrucosa sp. nov. & MBM286455 & $10.37^{\circ} \mathrm{N}, 140.04^{\circ} \mathrm{E}$ & present study & MW841034 & MW840138 & MW841044 \\
\hline Iridogorgia densispicula & MBM286538 & $10.35^{\circ} \mathrm{N}, 140.07^{\circ} \mathrm{E}$ & [7] & MK431864 & MW841037 & MW841040 \\
\hline Iridogorgia magnispiralis & MBM286450 & $10.50^{\circ} \mathrm{N}, 140.11^{\circ} \mathrm{E}$ & present study & MW841032 & MW841039 & MW841042 \\
\hline Iridogorgia squarrosa & MBM286539 & $11.16^{\circ} \mathrm{N}, 139.25^{\circ} \mathrm{E}$ & [7] & MK431865 & - & - \\
\hline Iridogorgia fontinalis & YPM 38584 & $34.81^{\circ} \mathrm{N}, 50.50^{\circ} \mathrm{W}$ & [6] & EU293802 & GQ868321 & - \\
\hline Iridogorgia magnispiralis & YPM: IZ: 38580 & - & $\begin{array}{c}\text { France, } \\
\text { unpublished }\end{array}$ & DQ860108 & - & - \\
\hline Iridogorgia magnispiralis & $\begin{array}{l}\text { MNHN-Oct.0000- } \\
0576\end{array}$ & $38.47^{\circ} \mathrm{N}, 27.9^{\circ} \mathrm{W}$ & [6] & GQ353316 & - & - \\
\hline Iridogorgia magnispiralis & - & $38.78^{\circ} \mathrm{N}, 63.96^{\circ} \mathrm{W}$ & {$[6]$} & EU268055 & - & - \\
\hline Iridogorgia magnispiralis & - & unknown & $\begin{array}{l}\text { France \& Pante, } \\
\text { unpublished }\end{array}$ & - & FJ268639 & - \\
\hline Iridogorgia magnispiralis & YPM 38580 & $38.78^{\circ} \mathrm{N}, 63.96^{\circ} \mathrm{W}$ & [6] & JN227997 & - & - \\
\hline Iridogorgia magnispiralis & - & $35.19^{\circ} \mathrm{N}, 47.68^{\circ} \mathrm{W}$ & [6] & GQ223116 & GQ868318 & - \\
\hline Iridogorgia magnispiralis & YPM 38581 & $38.26^{\circ} \mathrm{N}, 60.55^{\circ} \mathrm{W}$ & [6] & GQ180141 & - & - \\
\hline Iridogorgia magnispiralis & USNM 1092265 & $34.58^{\circ} \mathrm{N}, 56.84^{\circ} \mathrm{W}$ & [6] & GQ180142 & - & - \\
\hline Iridogorgia magnispiralis & YPM 38582 & $38.86^{\circ} \mathrm{N}, 63.91^{\circ} \mathrm{W}$ & [6] & GQ180140 & - & - \\
\hline Iridogorgia magnispiralis & - & Gulf of Mexico & {$[28,29]$} & KC788263 & KC788237 & KX890214 \\
\hline Iridogorgia sp. & _- & $21.32^{\circ} \mathrm{N}, 157.02^{\circ} \mathrm{W}$ & [6] & GQ868342 & GQ868323 & - \\
\hline Iridogorgia sp. & YPM 28866 & $33.79^{\circ} \mathrm{N}, 62.59^{\circ} \mathrm{W}$ & [6] & DQ297422 & - & - \\
\hline Iridogorgia sp. type C & - & $23.05^{\circ} \mathrm{N}, 163.16^{\circ} \mathrm{W}$ & [6] & JN227919 & - & - \\
\hline
\end{tabular}


Table 1. Cont.

\begin{tabular}{|c|c|c|c|c|c|c|}
\hline \multirow{2}{*}{ Species } & \multirow{2}{*}{ Voucher Number } & \multirow{2}{*}{ Locatiom } & \multirow{2}{*}{ References } & \multicolumn{3}{|c|}{ GenBank Accession Numbers } \\
\hline & & & & mtMutS & COI & $28 S$ rDNA \\
\hline Iridogorgia sp. type A & $\begin{array}{l}\text { MNHN-IC.2009- } \\
0001\end{array}$ & $9.15^{\circ} \mathrm{S}, 158.27^{\circ} \mathrm{E}$ & {$[6]$} & GQ180145 & - & - \\
\hline Iridogorgia splendens & YPM 35397, 38586 & $38.85^{\circ} \mathrm{N}, 63.76^{\circ} \mathrm{W}$ & [6] & DQ860109 & - & - \\
\hline Iridogorgia splendens & USNM 1092267 & $38.79^{\circ} \mathrm{N}, 64.13^{\circ} \mathrm{W}$ & {$[6]$} & JN227996 & GQ868313 & _- \\
\hline Iridogorgia splendens & YPM 38585 & $37.46^{\circ} \mathrm{N}, 59.95^{\circ} \mathrm{W}$ & {$[6]$} & JN228005 & GQ868330 & - \\
\hline Iridogorgia splendens & - & Gulf of Mexico & [28] & KC788271 & KC788229 & - \\
\hline Iridogorgia splendens & - & Gulf of Mexico & [29] & - & - & KX890215 \\
\hline Iridogorgia splendens & USNM 1092267 & $\begin{array}{l}\text { Kelvin Seamount, } \\
\text { NW Atlantic }\end{array}$ & [30] & GQ180143 & - & - \\
\hline Iridogorgia splendens & YPM: IZ: 38585 & $37.46^{\circ} \mathrm{N}, 59.95^{\circ} \mathrm{W}$ & [30] & GQ180144 & - & - \\
\hline Rhodaniridogorgia fragilis & YPM 38588 & $34.46^{\circ} \mathrm{N}, 56.73^{\circ} \mathrm{W}$ & [6] & JN228000 & JN227954 & - \\
\hline Chrysogorgia averta & - & Gulf of Mexico & [28] & КС788265 & КС788235 & КС788258 \\
\hline Chrysogorgia sp. & - & Gulf of Mexico & [28] & КС788268 & КС788223 & КС788240 \\
\hline Chrysogorgia sp. & - & Gulf of Mexico & [29] & - & - & KX890212 \\
\hline Pseudochrysogorgia bellona & $\begin{array}{c}\text { MNHN-IC.2008- } \\
007 \\
\text { Paratype }\end{array}$ & $21.12^{\circ} \mathrm{S}, 158.5^{\circ} \mathrm{E}$ & [6] & GQ868332 & GQ868310 & - \\
\hline Pseudochrysogorgia sp. & XMUB7697 & $15.52^{\circ} \mathrm{N}, 110.96^{\circ} \mathrm{E}$ & [31] & - & - & MW336977 \\
\hline Metallogorgia melanotrichos & - & $34.53^{\circ} \mathrm{N}, 47.79^{\circ} \mathrm{W}$ & [6] & GQ180158 & FJ268633 & - \\
\hline Metallogorgia macrospina & NIWA15642 & $37.21^{\circ} \mathrm{S}, 177.24^{\circ} \mathrm{E}$ & [6] & JN228001 & JN227952 & - \\
\hline Radicipes stonei & $\begin{array}{l}\text { USNM: } \\
\text { IZ:1418007 }\end{array}$ & Alaska & [32] & MG986912 & MG986961 & MG980134 \\
\hline Stephanogorgia faulkneri & NTM C014927 & $7.19^{\circ} \mathrm{N}, 134.32^{\circ} \mathrm{E}$ & [6] & GQ342485 & GQ342406 & JX203718 \\
\hline Chrysogorgiidae sp. & - & $41.37^{\circ} \mathrm{S}, 42.85^{\circ} \mathrm{E}$ & [33] & KP324387 & KP678004 & KP324611 \\
\hline Plexaura kuna & $\begin{array}{c}\text { RMNH } \\
\text { Coel.40836 }\end{array}$ & South Africa & [34] & JX203807 & JX203866 & JX203748 \\
\hline
\end{tabular}

New sequences are in bold.

\section{Results}

\subsection{Systematics}

Class Anthozoa Ehrenberg, 1834 [35].

Subclass Octocorallia Haeckel, 1866 [36].

Order Alcyonacea Lamouroux, 1812 [37].

Suborder Calcaxonia Grasshoff, 1999 [38].

Family Chrysogorgiidae Verrill, 1883 [10].

Genus Iridogorgia Verrill, 1883.

Diagnosis (based on Watling, 2007 [4]). Chrysogorgiids with main axis monopodial and spiraling upward, and undivided branches emanating from one side of axis. Polyps uniserially arranged, when sexually mature with base expanded along upper side of branch. Sclerites rods, spindles, or scales, extending in tracts onto tentacles. Branch coenenchyme with sclerites oriented along branch or absent between polyps.

Type species. Iridogorgia pourtalesii Verrill, 1883, by monotypy.

Distribution. Pacific: tropical Western Pacific, Hawaii, Southwest Pacific; Atlantic: North and Central East Atlantic; Indian Ocean: Great Australian Bay, depths 558-2311 m [4-8,10-14,39,40].

Iridogorgia flexilis sp. nov.

Figures $1 \mathrm{~A}-\mathrm{G}$ and 2; Table 2. 

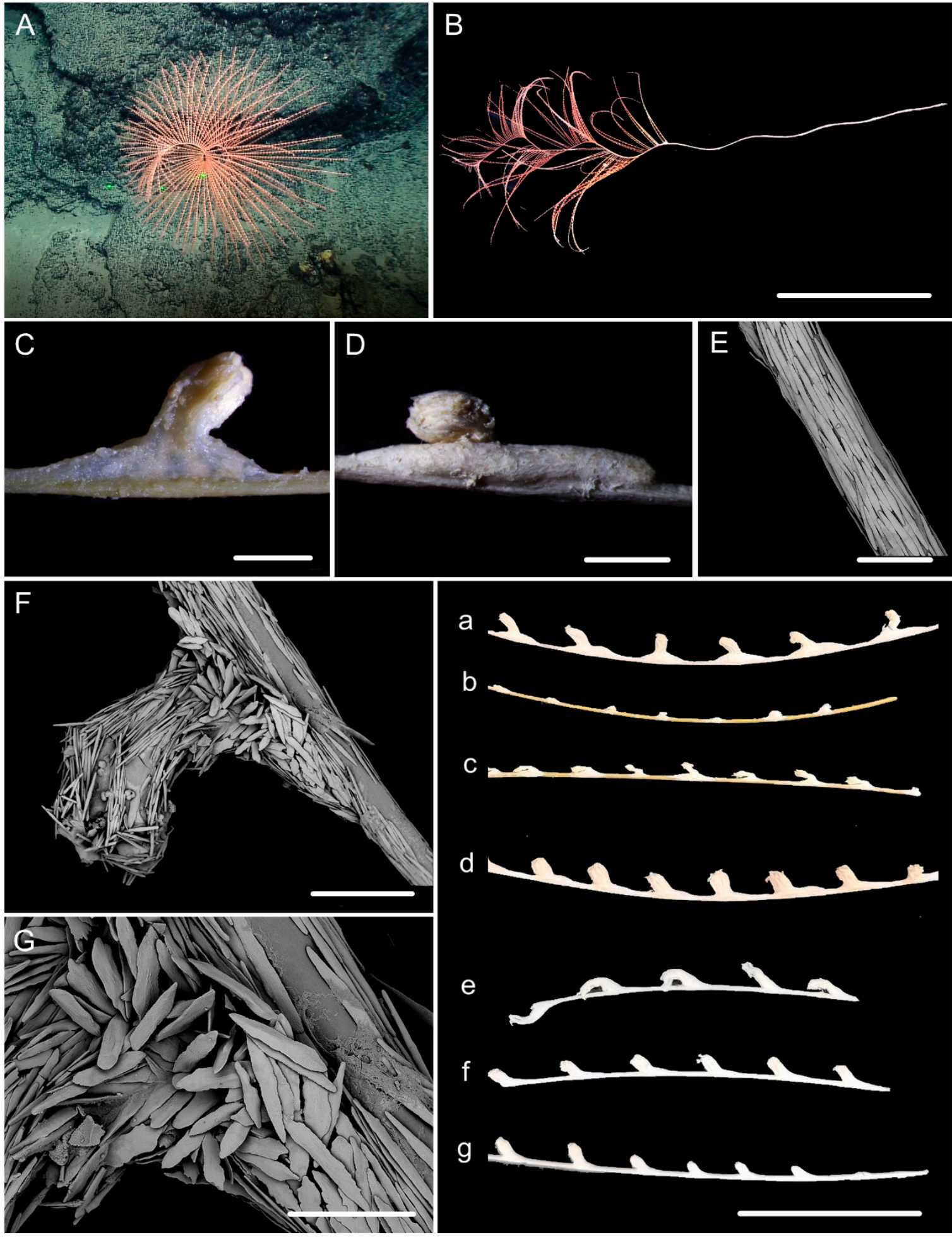

Figure 1. External morphology and polyps of Iridogorgia flexilis sp. nov. and different branch morphology of the Iridogorgia species in this passage (a-g). (A,B) The holotype in situ and after collection. Laser dots spaced at $33 \mathrm{~cm}$ used for measuring dimensions. (C,D) Single polyps under a light microscope. (E) A part of branch under SEM. (F) A single polyp under SEM. (G) Sclerites in basal polyp body under SEM. (a-g) A part of branch with different polyp size and arrangement, followed by I. flexilis sp. nov., I. densispiralis sp. nov., I. verrucosa sp. nov., I. magnispiralis, I. densispicula (MBM286446, 286447, 286448). Scales $=20 \mathrm{~cm}(\mathbf{B}), 2 \mathrm{~cm}$ (a-g in the same scale), $2 \mathrm{~mm}(\mathbf{C}, \mathbf{D}), 1 \mathrm{~mm}(\mathbf{F}), 500 \mu \mathrm{m}(\mathbf{E}, \mathbf{G})$. 
Table 2. Comparison of morphological and distributional characters of Iridogorgia species. "_" means missing data.

\begin{tabular}{|c|c|c|c|c|c|}
\hline Characters/Species & I. densispicula & I. squarrosa & I. bella & I. fontinalis & I. magnispiralis \\
\hline Each turn height $(\mathrm{cm})$ & $13-18$ & $13-15$ & - & 4 & $12-20$ \\
\hline Helical diameter $(\mathrm{cm})$ & $3-4$ & $4-5$ & - & 2.5 & $1-9$ \\
\hline Branch intervals (mm) & $3-4$ & $3-4$ & 4 & $1-2$ & $2-5$ \\
\hline Polyp height and width (mm) & $2-4 / 2-4$ & $2-4 / 1-2$ & - & $\begin{array}{c}1 \mathrm{~mm} \text { from branch to tentacle } \\
\text { base }\end{array}$ & $1-3 / 2-3$ \\
\hline Polyp intervals (mm) & $2-7$ & $2-6$ & 7 & $5-9$ & $2-7$ \\
\hline Verrucae & rare & a few & sparse & abundant & abundant \\
\hline Sclerites in coenenchyme $(\mu \mathrm{m})$ & $\begin{array}{l}\text { spindles usually with two sharp } \\
\text { ends: } 203-967 \times 11-65 \\
\text { spindles and scales coarse, }\end{array}$ & $\begin{array}{l}\text { spindles usually with two sharp } \\
\text { ends: } 180-840 \times 23-60\end{array}$ & - & $\begin{array}{l}\text { spindles and a few scales: } \\
397-1024 \times 25-74\end{array}$ & $\begin{array}{l}\text { spindles usually with two sharp } \\
\text { ends: } 322-1032 \times 21-81\end{array}$ \\
\hline Sclerites in polyp bodies $(\mu \mathrm{m})$ & $\begin{array}{l}\text { usually lobed with irregular } \\
\text { shape and rugged and ridged } \\
\text { surface in the upper part, and } \\
\text { regular and flat in the basal part: } \\
80-627 \times 14-110\end{array}$ & $\begin{array}{l}\text { scales with coarse surface and } \\
\text { various shape: } 72-569 \times 24-150\end{array}$ & needle-like or bar-shaped & rods: $175-482 \times 27-50$ & $\begin{array}{l}\text { spindles thick and slender, nearly } \\
\text { smooth or with many fine warts: } \\
\qquad 224-383 \times 23-57\end{array}$ \\
\hline Sclerites in tentacles $(\mu \mathrm{m})$ & rods: $137-945 \times 11-98$ & rods: $\begin{aligned} & 325-433 \times 26-43 \text { scales: } \\
& 467-805 \times 48-66\end{aligned}$ & needle-like or bar-shaped & shorter rods than bodies & rods: $157-548 \times 18-78$ \\
\hline Distribution & Western Pacific & Western Pacific & near Hawaii & North Atlantic & $\begin{array}{l}\text { North Atlantic, near Hawaii, } \\
\text { Western Pacific }\end{array}$ \\
\hline References & [7], present study & [7] & {$[6,7,11,13]$} & [4] & {$[4,8,11,14]$, present study } \\
\hline Characters/Species & I. pourtalesii & I. splendens & I. flexilis sp. nov. & I. densispiralis sp. nov. & I. verrucosa sp. nov. \\
\hline Each turn height $(\mathrm{cm})$ & - & 5 & $13-15$ & $2.5-3.0$ & $3-4$ \\
\hline Helical diameter $(\mathrm{cm})$ & - & $1-2$ & $3-4$ & 0.5 & 1 \\
\hline Branch intervals (mm) & $3-6$ & $3-4$ & 3 & $2-3$ & $1-3$ \\
\hline Polyp height and width (mm) & - & $\begin{array}{c}\text { less than } 1 \mathrm{~mm} \text { from branch to } \\
\text { tentacle base }\end{array}$ & $1-3 / 2-4$ & $1-2 / 1-3$ & $2 / 1-2$ \\
\hline Polyp intervals (mm) & 5 & $6-8.5$ & $4-6$ & $3-9$ & 4-6 \\
\hline Verrucae & numerous & numerous & rare & a few & numerous \\
\hline Sclerites in coenenchyme $(\mu \mathrm{m})$ & lacking in the inter- polyps & $\begin{array}{l}\text { scales and spindles under polyps; } \\
\text { absent to rare in the inter-polyps: } \\
\qquad 274-592 \times 24-51\end{array}$ & $\begin{array}{l}\text { spindles usually with two } \\
\text { rounded ends: } 322-892 \times 25-72\end{array}$ & $\begin{array}{l}\text { rods and spindles usually with } \\
\text { two rounded ends, sometimes } \\
\text { sparse in the inter-polyps: } 90-523 \\
\times 19-65\end{array}$ & $\begin{array}{l}\text { spindles same as the body wall, } \\
\text { usually with two rounded ends: } \\
169-438 \times 19-62\end{array}$ \\
\hline Sclerites in polyp bodies $(\mu \mathrm{m})$ & spindles smooth: average 400 & $\begin{array}{l}\text { scales with a constriction } \\
\text { midway: } 143-268 \times 29-45\end{array}$ & $\begin{array}{l}\text { spindles and scales stout and } \\
\text { thick with nearly smooth surface: } \\
172-679 \times 27-219\end{array}$ & $\begin{array}{c}\text { spindles, rods and a few } \\
\text { elongated scales often thick with } \\
\text { sparse and fine warts: } 84-347 \times \\
18-60\end{array}$ & $\begin{array}{l}\text { spindles and elongated scales } \\
\text { with sparse and fine warts and } \\
\text { irregular edges: } 116-450 \times 21-65\end{array}$ \\
\hline Sclerites in tentacles $(\mu \mathrm{m})$ & sparse rods: $200-900$ & few rods: $169-274 \times 27-39$ & rods: $261-532 \times 19-58$ & rods: $95-442 \times 11-52$ & rods: $160-459 \times 17-73$ \\
\hline Distribution & North Atlantic & North Atlantic & Western Pacific & Western Pacific & Western Pacific \\
\hline References & {$[4,10,11]$} & {$[4,6,11]$} & present study & present study & present study \\
\hline
\end{tabular}




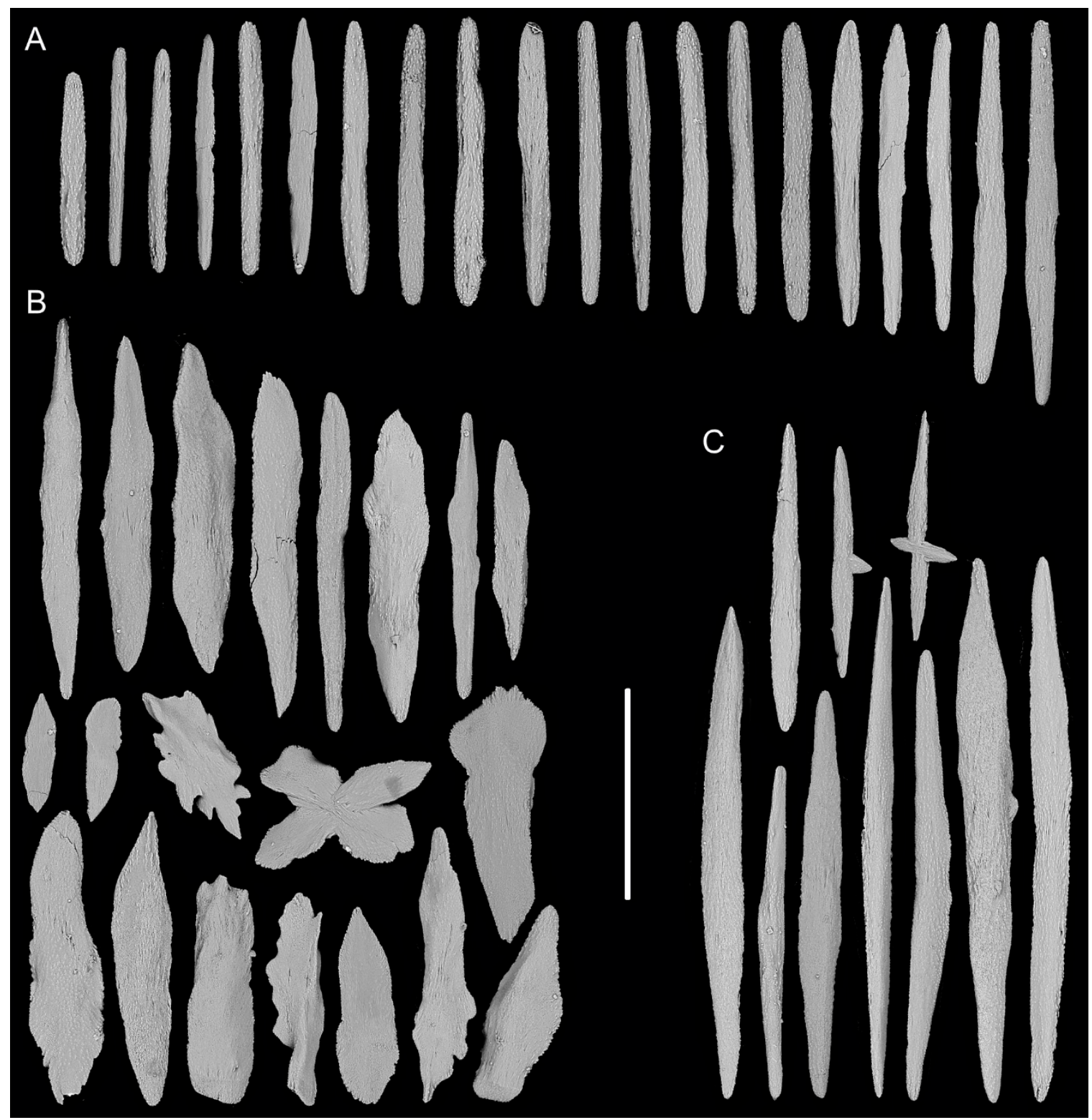

Figure 2. Sclerites of Iridogorgia flexilis sp. nov. (A) Sclerites in tentacle rachis. (B) Sclerites in polyp body wall. (C) Sclerites in coenenchyme. Scales $=300 \mu \mathrm{m}$, all in the same scale.

urn:lsid:zoobank.org:act:6BD2C9FC-9CD8-4604-971D-B2EC0BB108B8.

Material examined. Holotype: MBM286453, station FX-Dive $222\left(10^{\circ} 4.7^{\prime} \mathrm{N}, 140^{\circ} 9.28^{\prime} \mathrm{E}\right)$, a seamount (temporarily named as M5) on the Caroline Ridge, 2016 m, 10 June 2019.

Diagnosis. Colony having a long unbranched part with branches producing on the top. Axis loosely coiled on the top with helical turn $12-15 \mathrm{~cm}$ high. Polyps having a broad body base with its width usually longer than the height. Rods in the back of tentacle rachis longitudinally arranged, slender with more or less warts. Spindles and scales in polyp body wall transversely or obliquely arranged, stout and thick, occasionally crossed with irregular edges. Spindles in coenenchyme slender and thick, occasionally branched. Verrucae rare in branches.

Description. Holotype is incomplete colony without holdfast, about $85 \mathrm{~cm}$ long (Figure 1B). The direction of growth clockwise. Axis about $4 \mathrm{~mm}$ in diameter at base with iridescent metallic luster. The branching part about $34 \mathrm{~cm}$ long including three loosely heli- 
cal turns with each helical turn $12-15 \mathrm{~cm}$ long and 3-4 cm in diameter. Branches arranged along one side, about $3 \mathrm{~mm}$ apart, up to $28 \mathrm{~cm}$ long with 39 polyps counted. Polyps have a broad body base with its width usually longer than the height, forming a contraction at the base of the tentacular part (Figure 1C,D). Polyps 4-6 mm apart, 1-3 mm tall, and 2-4 mm wide at base (Figure 1a). Tentacular part about $1 \mathrm{~mm}$ long, 1.0-1.5 mm wide, composed of numerous rods usually forming eight obvious parallel columns terminating at its base. Polyps white after fixation in alcohol. Verrucae rare in branches.

Rods in the back of tentacle rachis longitudinally arranged, slender with two round ends, surface usually with numerous small conical or ridge-like warts, occasionally with sparse warts or shallow cracks, measuring 261-532 × 19-58 $\mu \mathrm{m}$ (Figures 1F and 2A). Spindles and scales in polyp body wall transversely or obliquely arranged, stout and thick, occasionally crossed with irregular edges or various shapes, measuring 172-679 $\times 27-219 \mu \mathrm{m}$ (Figures $1 \mathrm{G}$ and $2 \mathrm{~B}$ ). Their surface usually with sparse and fine warts, occasionally nearly smooth or with large protuberances and some shallow cracks. Spindles in coenenchyme slender and thick, usually with two rounded ends, nearly smooth or with sparse and fine warts, and occasionally branched or with narrow or sharp ends, measuring 322-892 × 25-72 $\mu \mathrm{m}$ (Figures 1E and 2C).

Type locality. A seamount (temporarily named as M5) located on the Caroline Ridge in the Western Pacific with water depth of $2016 \mathrm{~m}$.

Etymology. The Latin adjective flexilis (flexile) refers to the flexile axis of this species.

Distribution and Habitat. Found only from a seamount located on the Caroline Ridge. Grown in a rocky bottom with the water temperature about $2.1^{\circ} \mathrm{C}$ and salinity 36.5 (Figure 1A).

Remarks. Iridogorgia flexilis sp. nov. is characterized by its highly helical turns, broad polyp body base with stout and thick spindles and scales. It is similar to I. magnispiralis Watling, 2007 and I. densispicula Xu et al., 2020 in the helical turn, but differs distinctly from I. magnispiralis by the presence of scales in polyp body wall (vs. absent), from I. densispicula by the thick and relatively smooth sclerites in the polyp body wall (vs. very thin and coarse often with rugged and ridged surface) [4,7].

Iridogorgia densispiralis sp. nov.

Figures $1 \mathrm{~b}, 3$ and 4 ; Table 2.

urn:lsid:zoobank.org:act:026E2F14-7A66-4558-9D65-B7E3CC0EC8D0.

Material examined. Holotype: MBM286454, station FX-Dive $225\left(10^{\circ} 36.75^{\prime} \mathrm{N}, 140^{\circ} 3.85^{\prime} \mathrm{E}\right)$, a seamount (temporarily named as M8) located on the Caroline Ridge, 1574 m, 13 June 2019.

Diagnosis. Colony relatively short. Axis have many close helical turns each $2.5-3.0 \mathrm{~cm}$ high. Polyps small with an expanded and conical body base. Rods in tentacle rachis longitudinally arranged, usually with many small warts. Spindles, rods and a few elongated scales in polyp body wall transversely or obliquely arranged, usually thick with sparse and fine warts. Rods and spindles in coenenchyme thick and nearly smooth or with sparse and fine warts. Branches with a few verrucae.

Description. Holotype orange in situ, about $48 \mathrm{~cm}$ long with the holdfast not recovered (Figure 3A,B). The direction of growth clockwise. Axis about $3 \mathrm{~mm}$ in diameter at base with branches producing nearly from the bottom to top and light iridescent metallic luster. Axis has 13 helical turns each $2.5-3.0 \mathrm{~cm}$ high and $0.5 \mathrm{~cm}$ wide. Branches usually grow upward, arranged along one side, 2-3 mm apart. Branches almost incomplete after collection and up to $11 \mathrm{~cm}$ long with 14 polyps counted. Polyps small, 3-9 $\mathrm{mm}$ apart, $1-2 \mathrm{~mm}$ tall and 1-3 mm wide at base (Figures $1 \mathrm{~b}$ and $3 \mathrm{C}-\mathrm{E}$ ). Tentacular part about $1.0-1.5 \mathrm{~mm}$ long and wide, situated at an acute angle with the branch. Polyps white after fixation in alcohol. A few large verrucae present at polyp base and branches. 

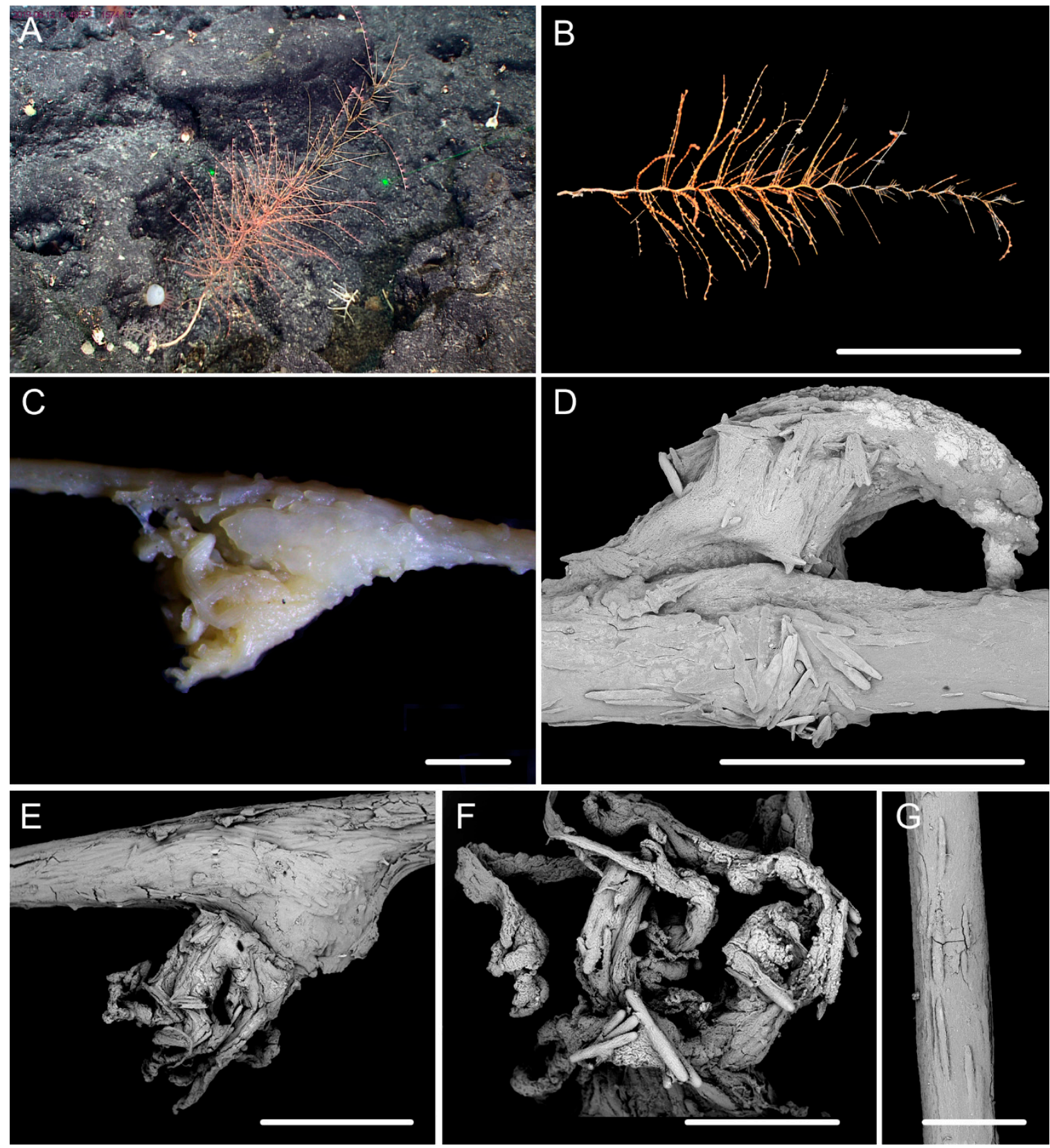

Figure 3. External morphology and polyps of Iridogorgia densispiralis sp. nov. (A) The holotype in situ. (B) The holotype after collection. (C) A single polyp under a light microscope. (D,E) Singles polyps under SEM. (F) Tentacular part under SEM. (G) A part of branch under SEM. Scales $=20 \mathrm{~cm}(\mathbf{B}), 1 \mathrm{~mm}(\mathbf{C}-\mathbf{E}), 500 \mu \mathrm{m}(\mathbf{F}, \mathrm{G})$. 


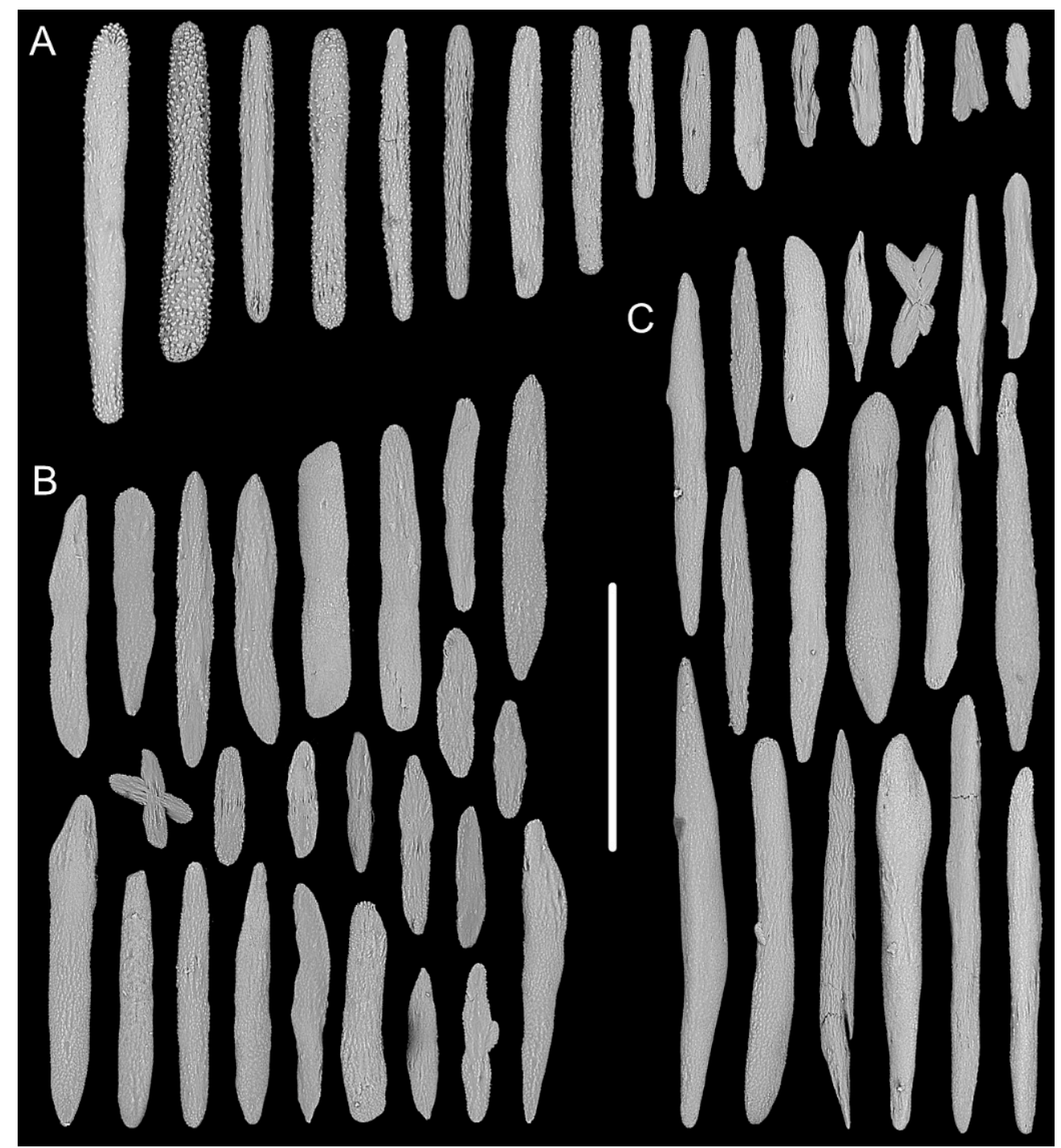

Figure 4. Sclerites of Iridogorgia densispiralis sp. nov. (A) Sclerites in tentacle rachis. (B) Sclerites in polyp body wall. (C) Sclerites in coenenchyme. Scales $=300 \mu \mathrm{m}$, all in the same scale.

Rods in the back of tentacle rachis longitudinally arranged, with many small warts and two rounded ends, sometimes with deep cracks or a few warts, measuring 95-442 $\times 11-52 \mu \mathrm{m}$ (Figures $3 \mathrm{~F}$ and $4 \mathrm{~A}$ ). Spindles, rods and a few elongated scales in polyp body wall transversely or obliquely arranged, often thick with sparse and fine warts, occasionally branched or crossed with shallow cracks on surface, measuring 84-347 $\times 18-60 \mu \mathrm{m}$ (Figure 4B). Rods and spindles in coenenchyme, thick with two sharp or round ends, nearly smooth or with sparse and fine warts, occasionally crossed, measuring 90-523 $\times 19-65 \mu \mathrm{m}$ (Figures $3 \mathrm{G}$ and $4 \mathrm{C}$ ). Sclerites sometimes sparse in the coenenchyme between polyps.

Type locality. A seamount (tentatively named as M8) located on the Caroline Ridge in the Western Pacific with water depth of $1574 \mathrm{~m}$.

Etymology. Composite of the Latin adjectives densus (dense) and spiralis (spiral), referring to the dense spirals of this species.

Distribution and Habitat. Found only from a seamount located on the Caroline Ridge. Grown in a rocky bottom with branches in upper part of the colony incomplete (Figure 3A).

Remarks. Iridogorgia densispiralis sp. nov. is characterized by the relatively short colony, short and narrow helical turn, and rods present in both polyps and coenenchyme. It is most similar to I. splendens Watling, 2007 in the relatively short colony and helical turn in 
adults, but differs by the presence of thick rods in coenenchyme (vs. absent) and abundant sclerites in tentacles (vs. sparse) [4].

Iridogorgia verrucosa sp. nov.

Figures 1c, 5 and 6; Table 2.
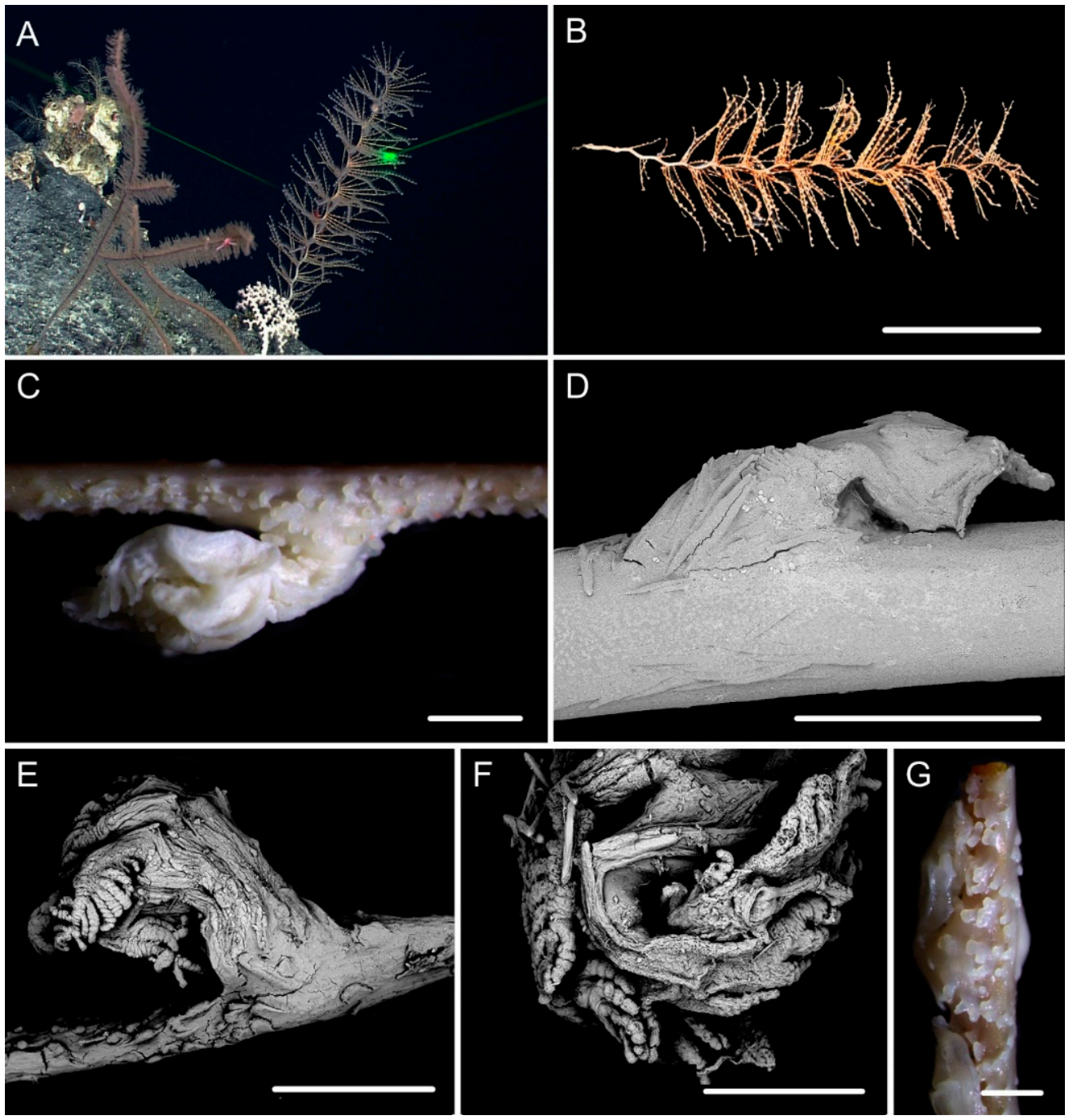

Figure 5. External morphology and polyps of Iridogorgia verrucosa sp. nov. (A) The holotype in situ. (B) The holotype after collection. (C) A single polyp under a light microscope. (D,E) Single polyps under SEM. (F) Tentacular part under SEM.

(G) Coenenchyme with many verrucae under a light microscope. Scales = $20 \mathrm{~cm}(\mathbf{B}), 1 \mathrm{~mm}(\mathbf{C}-\mathbf{E}, \mathrm{G}), 500 \mu \mathrm{m}(\mathbf{F})$.

urn:lsid:zoobank.org:act:E388B7B2-936E-485C-AB38-E7F95DD4F0A4.

Material examined. Holotype: MBM286455, station FX-Dive $225\left(10^{\circ} 36.77^{\prime} \mathrm{N}, 140^{\circ} 04.05^{\prime} \mathrm{E}\right)$, a seamount (temporarily named as M8) located on the Caroline Ridge, 1397 m, 13 June 2019.

Diagnosis. Colony relatively short with branches producing nearly from the bottom to top. Axis having many close helical turns each $3-4 \mathrm{~cm}$ in high. Polyps small with long tentacles. Rods in tentacle rachis longitudinally arranged and usually with many small warts. Spindles and elongated scales in polyp body wall transversely or obliquely placed, thick with irregular edges. Spindles in coenenchyme slender and thick with usually rounded ends. Branches with many cylindroid verrucae.

Description. Holotype orange, about $51 \mathrm{~cm}$ long with the holdfast not recovered (Figure 5B). Growth direction clockwise. Axis about $4 \mathrm{~mm}$ in diameter at base with branches producing nearly from bottom to top, composed of 14 helical turns each about $3-4 \mathrm{~cm}$ high and $1 \mathrm{~cm}$ wide. Branches usually growing upward, arranged along one side, 
1-3 mm apart. Branches almost incomplete after collection, up to $10 \mathrm{~cm}$ long with 14 polyps counted. Polyps small, towards to the branch end and situated with an acute angle, 4-6 mm apart, average $2 \mathrm{~mm}$ tall, and $1-2 \mathrm{~mm}$ wide at base (Figures $1 \mathrm{c}$ and $5 \mathrm{C}-\mathrm{E}$ ). Tentacular part up to $2 \mathrm{~mm}$ long and $1 \mathrm{~mm}$ wide. Polyps white after fixation in alcohol. Numerous and dense small cylindroid verrucae present in polyp base and branches (Figure 5C,G).

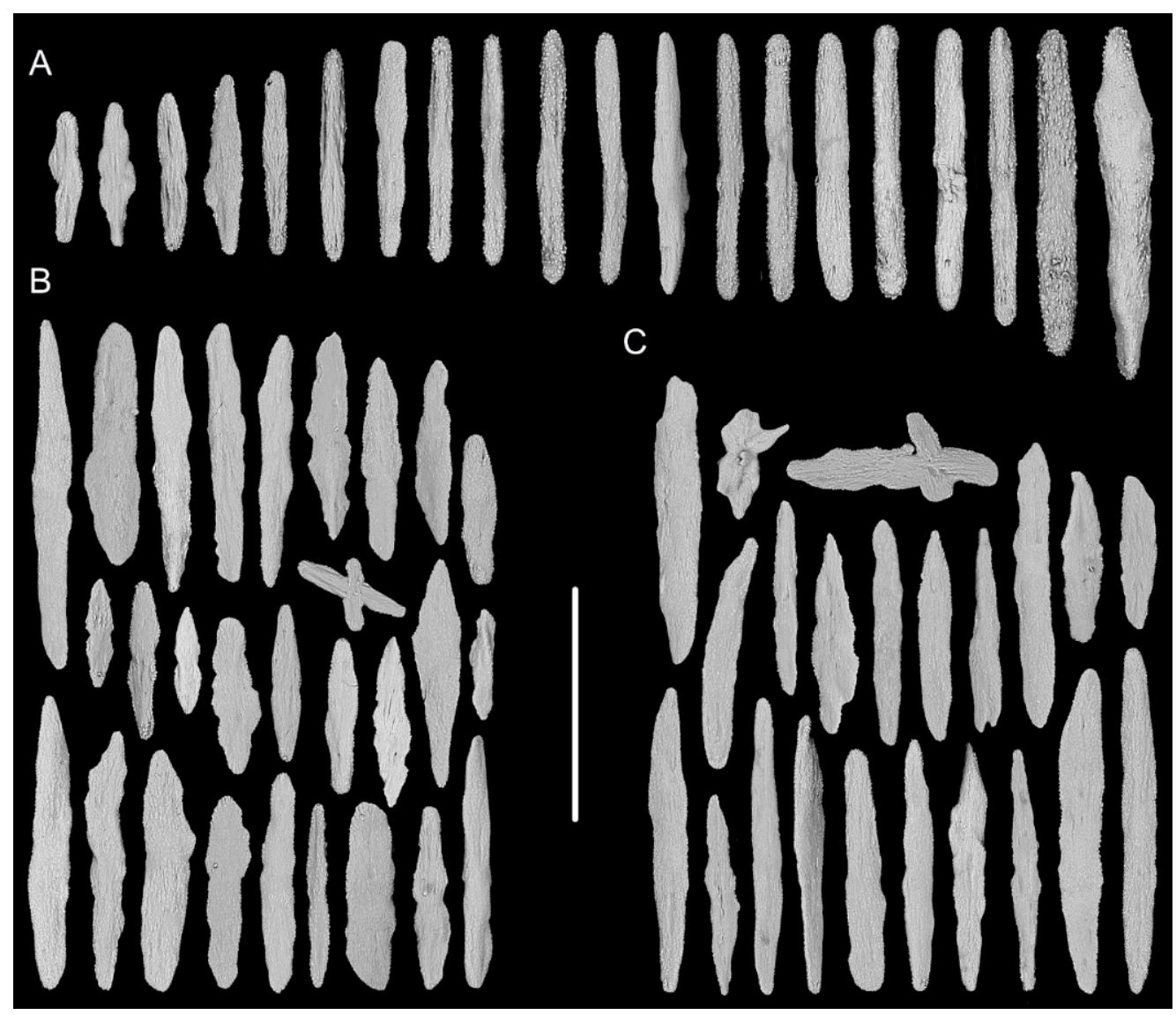

Figure 6. Sclerites of Iridogorgia verrucosa sp. nov. (A) Sclerites in tentacle rachis. (B) Sclerites in polyp body wall. (C) Sclerites in coenenchyme. Scales $=300 \mu \mathrm{m}$, all in the same scale.

Rods in the back of tentacle rachis longitudinally arranged, usually with many small conical warts and round ends, sometimes with deep cracks on surface, occasionally lobed with irregular edges, measuring 160-459 $\times 17-73 \mu \mathrm{m}$ (Figures 5F and 6A). Spindles and elongated scales in polyp body wall transversely or obliquely placed, usually thick with sparse and fine warts and irregular edges, measuring 116-450 $\times 21-65 \mu \mathrm{m}$ (Figure 6B). Spindles in coenenchyme very similar to those in polyp body wall, almost slender, measuring

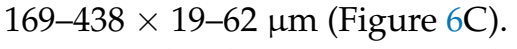

Type locality. A seamount (temporarily named as M8) located on the Caroline Ridge in the Western Pacific with water depth of $1397 \mathrm{~m}$.

Etymology. The Latin adjective verrucosus (verrucose) refers to the numerous small verrucae of this species.

Distribution and Habitat. Found only from a seamount located on the Caroline Ridge. Grown in a rocky bottom with black coral and scleractinian coral living around (Figure 5A).

Remarks. Iridogorgia verrucosa sp. nov. is characterized by the relatively short colony and narrow helical turn, irregular spindles and scales in polyp body wall and numerous verrucae. It is similar to I. splendens and I. densispiralis sp. nov. in the short colony and close helix, but differs from I. splendens by the abundant rods in tentacles (vs. sparse), sclerites in polyp body wall with irregular edges (vs. regular), and numerous sclerites in inter-polyp 
coenenchyme (vs. rare to absent) [4]. Iridogorgia verrucosa sp. nov. can be distinguished from $I$. densispiralis sp. nov. by the absence of rods in coenenchyme (vs. present) and numerous and dense verrucae in branches (vs. sparse).

Iridogorgia magnispiralis Watling, 2007.

Figures $1 \mathrm{~d}, 7$ and 8; Table 2.
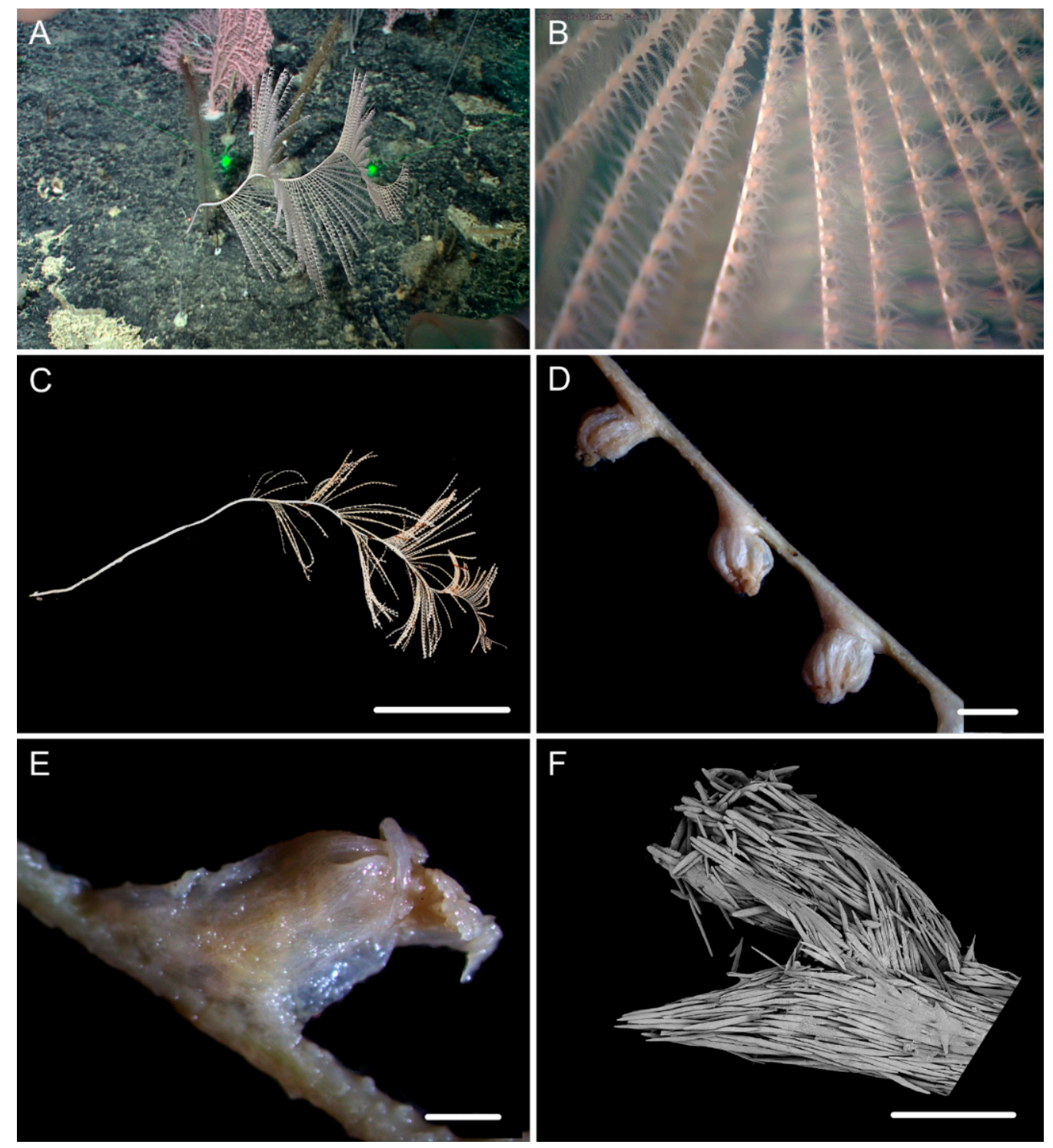

Figure 7. External morphology and polyps of Iridogorgia magnispiralis Watling, 2007. (A) The specimen MBM286451 in situ. Laser dots spaced at $33 \mathrm{~cm}$ used for measuring dimensions. (B) Close-up of branches and polyps in situ. (C) The specimen MBM286451 after collection. (D) A part of branch with three polyps under a light microscope. (E) A single polyp under a light microscope. (F) A single polyp under SEM. Scales = $20 \mathrm{~cm}(\mathbf{C}), 2 \mathrm{~mm}(\mathbf{D}), 1 \mathrm{~mm}(\mathbf{E}, \mathbf{F})$.

Iridogorgia magnispiralis Watling, 2007: 395-397, Figures 2 and 3.

Material Examined. MBM286450 and MBM286451, station FX-Dive $216\left(10^{\circ} 5.15^{\prime} \mathrm{N}\right.$, $140^{\circ} 11.12^{\prime} \mathrm{E}$ ), a seamount (tentatively named as M5) located on the Caroline Ridge in the Western Pacific, 845 m, 4 June 2019.

Diagnosis (based on the present specimens and Watling, 2007 [4]). Colony with branches producing on upper part, and helical turn each 12-20 cm high. Polyps erect or slightly inclined along branches. Rods in tentacle rachis longitudinally arranged, regular with many small warts. Spindles in polyp body wall transversely or obliquely arranged, slender and nearly smooth. Spindles in coenenchyme transversely arranged, slender with 
two sharp ends and nearly smooth surface. Scales absent. Branches with many verrucae. Inter-polyp coenenchyme with numerous sclerites.

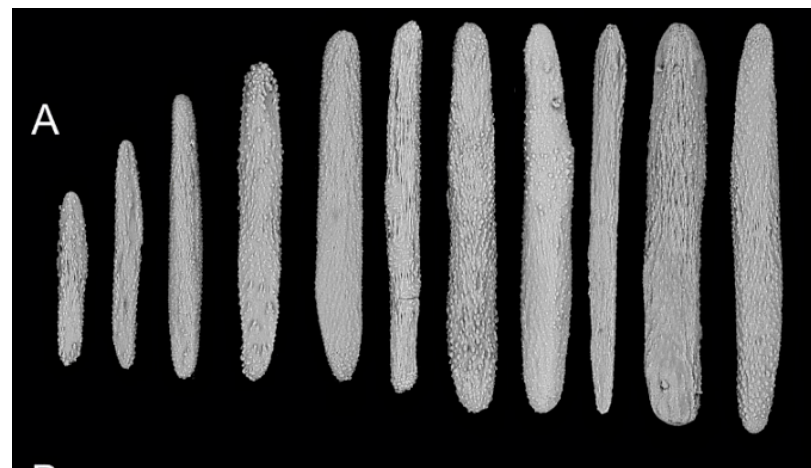

B
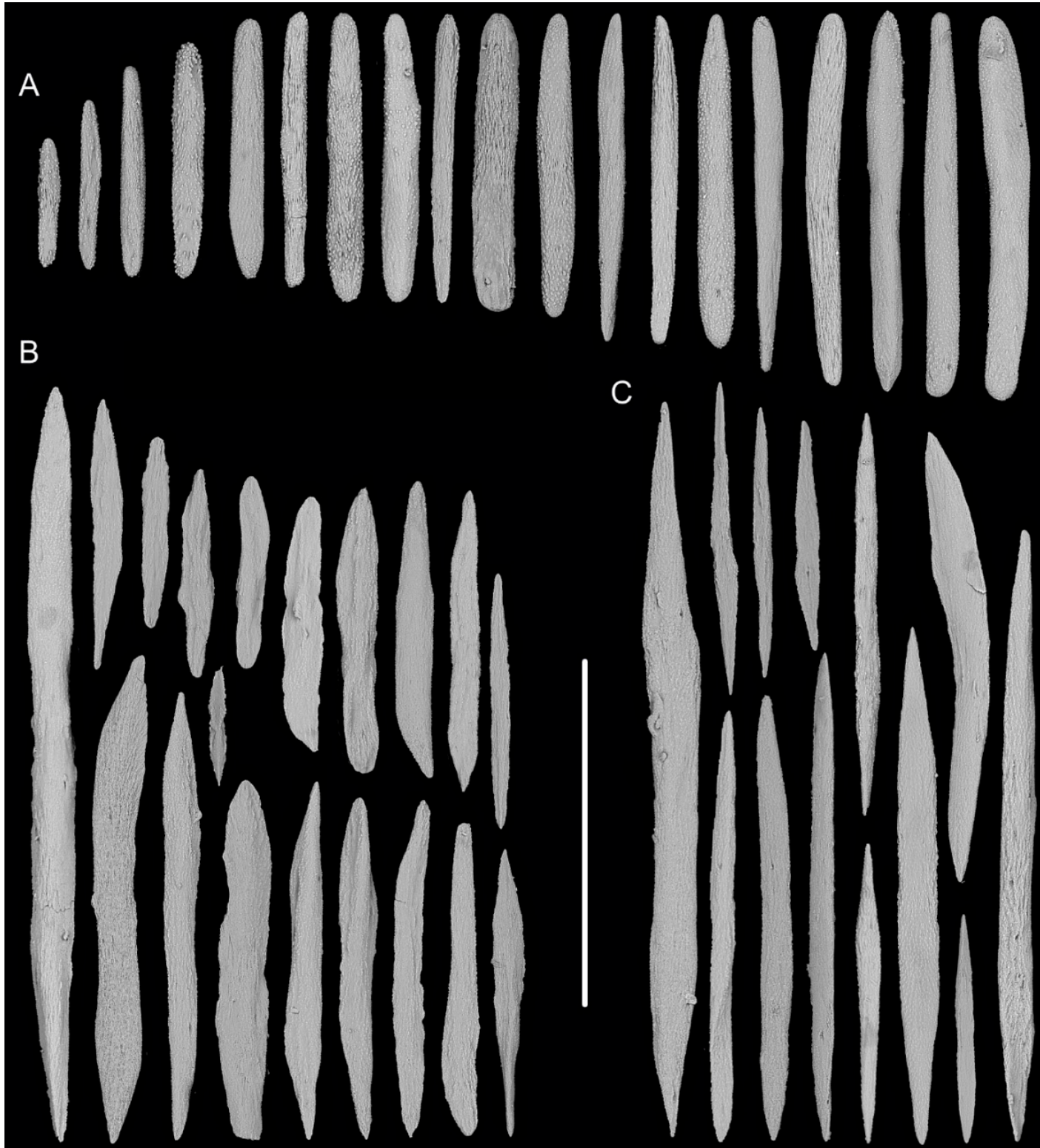

C

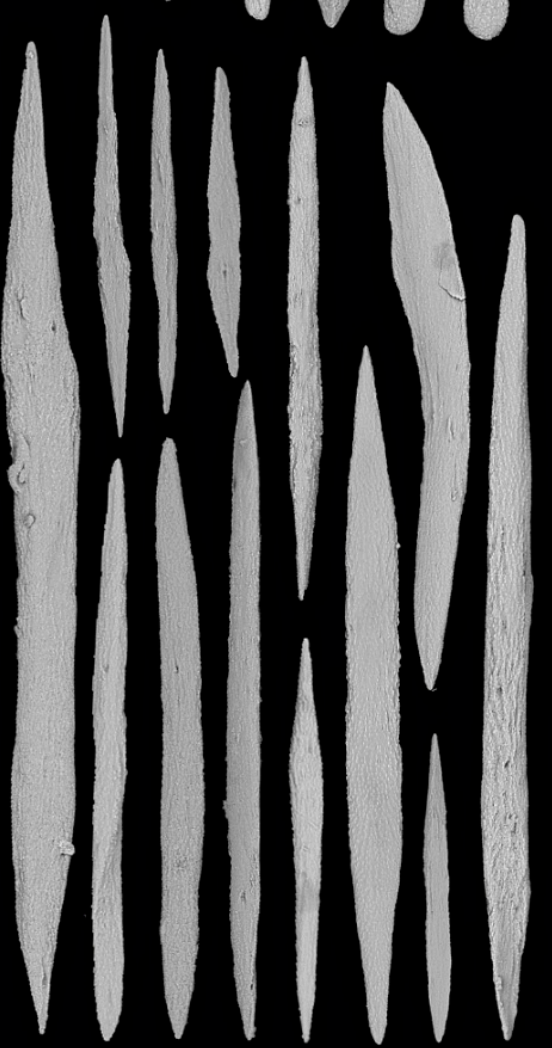

Figure 8. Sclerites of Iridogorgia magnispiralis Watling, 2007 (MBM286451). (A) Sclerites in tentacle rachis. (B) Sclerites in polyp body wall. (C) Sclerites in coenenchyme. Scales $=500 \mu \mathrm{m}$, all in the same scale.

Description. Two specimens have similar external morphology and size, and the specimen MBM286451 was described in detail here. Colony grown in a rocky bottom with a small holdfast in situ (Figure 7A). Specimen about $63 \mathrm{~cm}$ long with the holdfast not recovered (Figure 7C). The direction of growth clockwise and the same in MBM286450. Axis about $2.5 \mathrm{~mm}$ in diameter at base with branches producing on the upper part, having two helical turns each about $12 \mathrm{~cm}$ high and $1 \mathrm{~cm}$ in diameter. Branches arranged along one side, about $2 \mathrm{~mm}$ apart and up to $13.5 \mathrm{~cm}$ long with 21 polyps counted. Polyps erect or slightly inclined along the branches, 2-4 $\mathrm{mm}$ apart, 1-3 $\mathrm{mm}$ long, and 2-3 $\mathrm{mm}$ wide at base (Figures $1 \mathrm{~d}$ and 7B,D-F). Tentacular part 1.0-1.5 mm long and wide. Polyps white after fixation in alcohol. Branches with many low verrucae.

Rods in the back of tentacle rachis longitudinally arranged, regular with two rounded ends, often with many small conical warts, occasionally with some shallow cracks and 
a few warts on surface, measuring 157-548 $\times 18-78 \mu \mathrm{m}$ (Figure $8 \mathrm{~A}$ ). Spindles in polyp body wall transversely or obliquely arranged, thick, slender and usually with two sharp ends, nearly smooth or with many fine warts, occasionally rugged or with a few large protuberances, measuring 214-1054 × 28-65 $\mu \mathrm{m}$ (Figure 8B). Spindles in coenenchyme slender with two sharp ends, nearly smooth, occasionally with a few large irregular protuberances, measuring 332-1032 $\times 21-81 \mu \mathrm{m}$ (Figure $8 \mathrm{C}$ ). Scales absent in this specimen (Figures 7F and 8). Inter-polyp coenenchyme with numerous sclerites.

Distribution. The western Corner Rise Seamounts to the New England Seamounts to Kelvin Seamount, and the Lost City site on the Mid-Atlantic Ridge, 1650-2400 m [4]; Hawaii, 1310-1366 m [6,8]; Phoenix Islands Protected Area, 1000-2000 m [14]; Northeast Australia, 728-777 m [6]; a seamount located on the Caroline Ridge, $845 \mathrm{~m}$.

Remarks. The present specimens match well with the holotype of Iridogorgia magnispiralis Watling, 2007. The smaller number of the helical turns and the shorter branches suggest the two specimens are in a young stage.

Iridogorgia densispicula $\mathrm{Xu}, \mathrm{Zhan}, \mathrm{Li}$ and $\mathrm{Xu}, 2020$.

Figures 1e-g, 9, 10A-E and 11-13; Table 2.
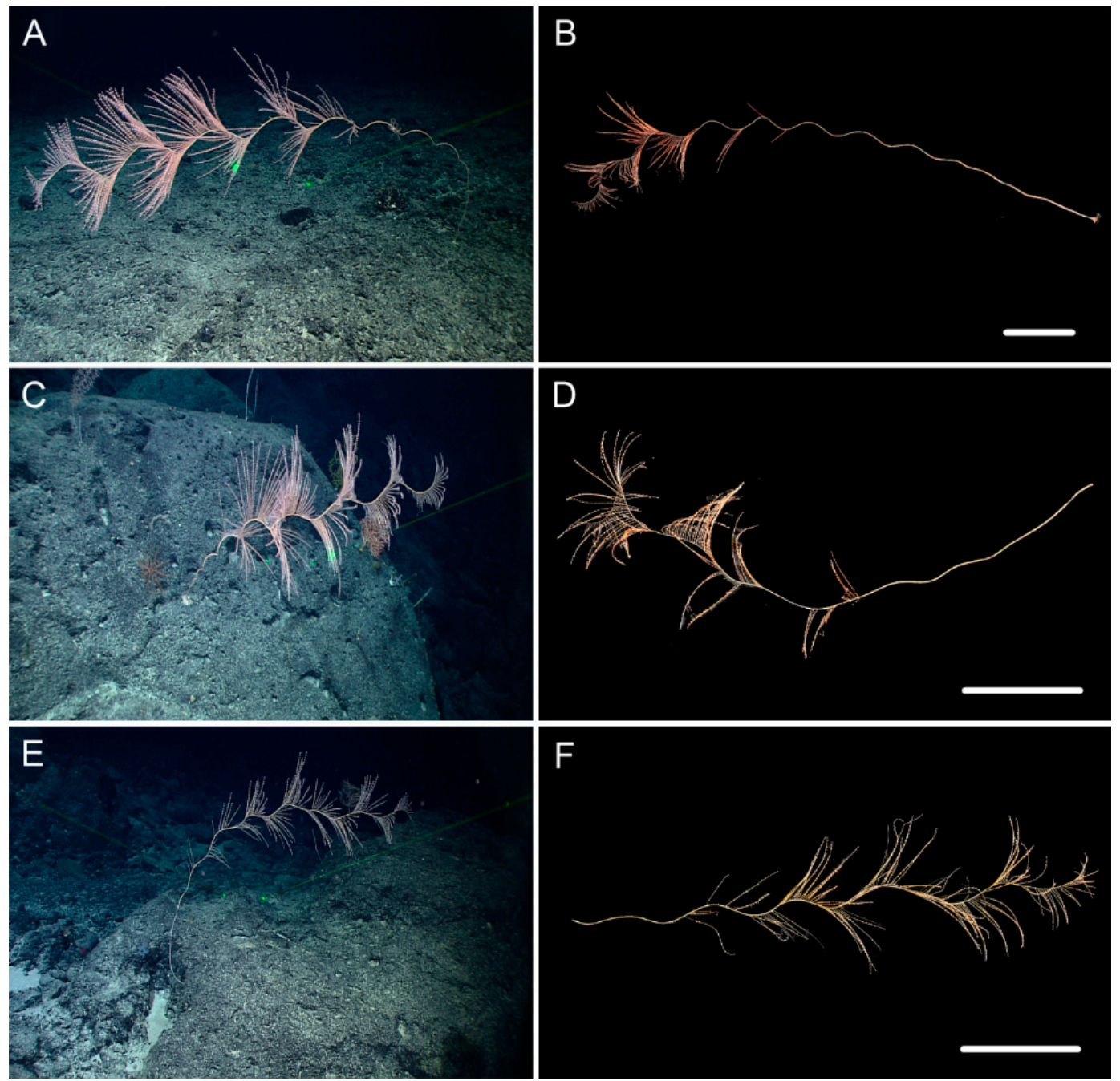

Figure 9. External morphology of Iridogorgia densispicula Xu et al., 2020 specimens MBM286446 (A,B), MBM286447 (C,D) and MBM286448 (E,F). (A,C,E) Specimens in situ. (B,D,F) Specimens after collection. Scales $=20 \mathrm{~cm}(\mathbf{B}, \mathbf{D}, \mathbf{F})$. 


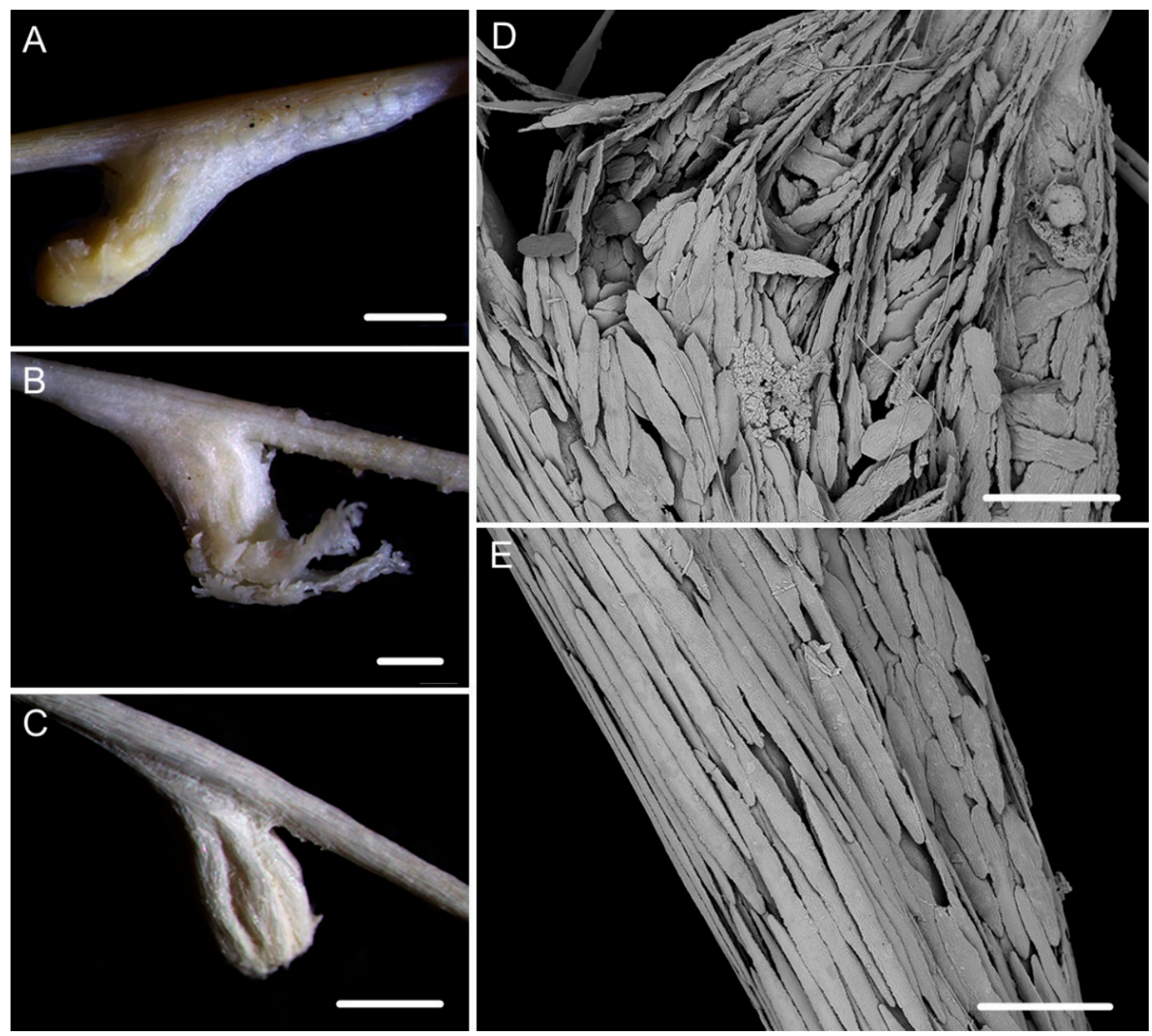

Figure 10. Polyps and sclerites arrangement of Iridogorgia densispicula Xu et al., 2020 (A-E). (A-C) Single polyps under a light microscope, specimens MBM286446, MBM286447 and MBM286448, respectively. (D) Polyp body under SEM. (E) Conenechyme and the end of basal body under SEM. Scales $=1 \mathrm{~mm}(\mathbf{A}-\mathbf{C}), 300 \mu \mathrm{m}(\mathbf{D}, \mathbf{E})$.

Iridogorgia densispicula Xu, Zhan, Li \& Xu, 2020: 251-254, Figures 2 and 3.

Material Examined. MBM286446, station FX-Dive $226\left(10^{\circ} 38.8^{\prime} \mathrm{N}, 140^{\circ} 4.15^{\prime} \mathrm{E}\right)$, a seamount (tentatively named as M8) located on the Caroline Ridge, $1741 \mathrm{~m}, 14$ June 2019. MBM286447, station FX-Dive $227\left(10^{\circ} 37.88^{\prime} \mathrm{N}, 140^{\circ} 5.62^{\prime} \mathrm{E}\right)$, a seamount (tentatively named as M8) located on the Caroline Ridge, 1678 m, 15 June 2019. MBM286448, station FXDive $211\left(10^{\circ} 2.93^{\prime} \mathrm{N}, 140^{\circ} 10.48^{\prime} \mathrm{E}\right)$, a seamount (tentatively named as M5) located on the Caroline Ridge, 1482 m, 29 May 2019.

Improved diagnosis (based on the present specimens and $\mathrm{Xu}$ et al. 2020 [7]). Colony slender with branches producing on the upper part. Axis having helical turns each 12-19 cm high. Polyps usually inclined towards distal end of branch. Rods in tentacle rachis longitudinally arranged, regular with many small conical or ridge-like warts on surface and two rounded ends. Spindles and scales in polyp body wall transversely or obliquely arranged, elongated with irregular edges and often rugged and ridged surface. Spindles in coenenchyme slender and usually with two sharp ends. Branch surface nearly smooth, rarely with verrucae.

Description. The three specimens are similar in external morphology, and only the specimen MBM286446 was descripted in detail here. Colony grown in a rocky bottom with a small white holdfast in situ (Figure 9A). Specimen about $73 \mathrm{~cm}$ long with the holdfast not recovered (Figure 9B). The direction of growth counterclockwise (clockwise in MBM286447, counterclockwise in the bottom branching part and clockwise in the upper in MBM286448). Axis about $2.5 \mathrm{~mm}$ in diameter at base with dark iridescent metallic luster and having 
six helical turns, each turn 16-18 cm long and 3-4 cm in diameter. The branching part about $19 \mathrm{~cm}$ long with branches growing upward and not arc-shaped. Branches arranged along one side, 3-4 mm apart, and up to $20 \mathrm{~cm}$ long with 29 polyps counted. Polyps usually inclined towards distal end of branch, 2-4 mm apart, average $2.5 \mathrm{~mm}$ long, and 2-4 mm wide at base (Figures $1 \mathrm{e}$ and 10A). Tentacular part 1-2 mm long, $1 \mathrm{~mm}$ wide, usually forming eight obvious parallel columns terminating at its base (Figure 10C). Polyps sometimes with an expanded body base and golden eggs present and visible under the microscope (Figure 10A). Polyps became white after fixation. Branch surface nearly smooth, rarely with a few verrucae.

Rods in the back of tentacle rachis longitudinally arranged, slender and regular with usually two round ends and many small conical or ridge-like warts, occasionally branched and with a few large protuberances, measuring 137-519 × 11-52 $\mu \mathrm{m}$ (Figure 11A). Spindles and scales in polyp body wall transversely or obliquely arranged, elongate and often with a slight midway constriction and many fine warts, usually lobed with irregular shape and rugged and ridged surface in the upper part of the body wall (Figure 10D), and regular and flat in the basal part (Figure 10E), measuring 80-540 × 14-101 $\mu \mathrm{m}$ (Figure 11B). Spindles in coenenchyme slender, usually with two sharp ends and many fine warts on surface, occasionally nearly smooth or with a few irregular protuberances, measuring 203-967 × 11-65 $\mu \mathrm{m}$ (Figure 11C). Inter-polyp coenenchyme with numerous sclerites.

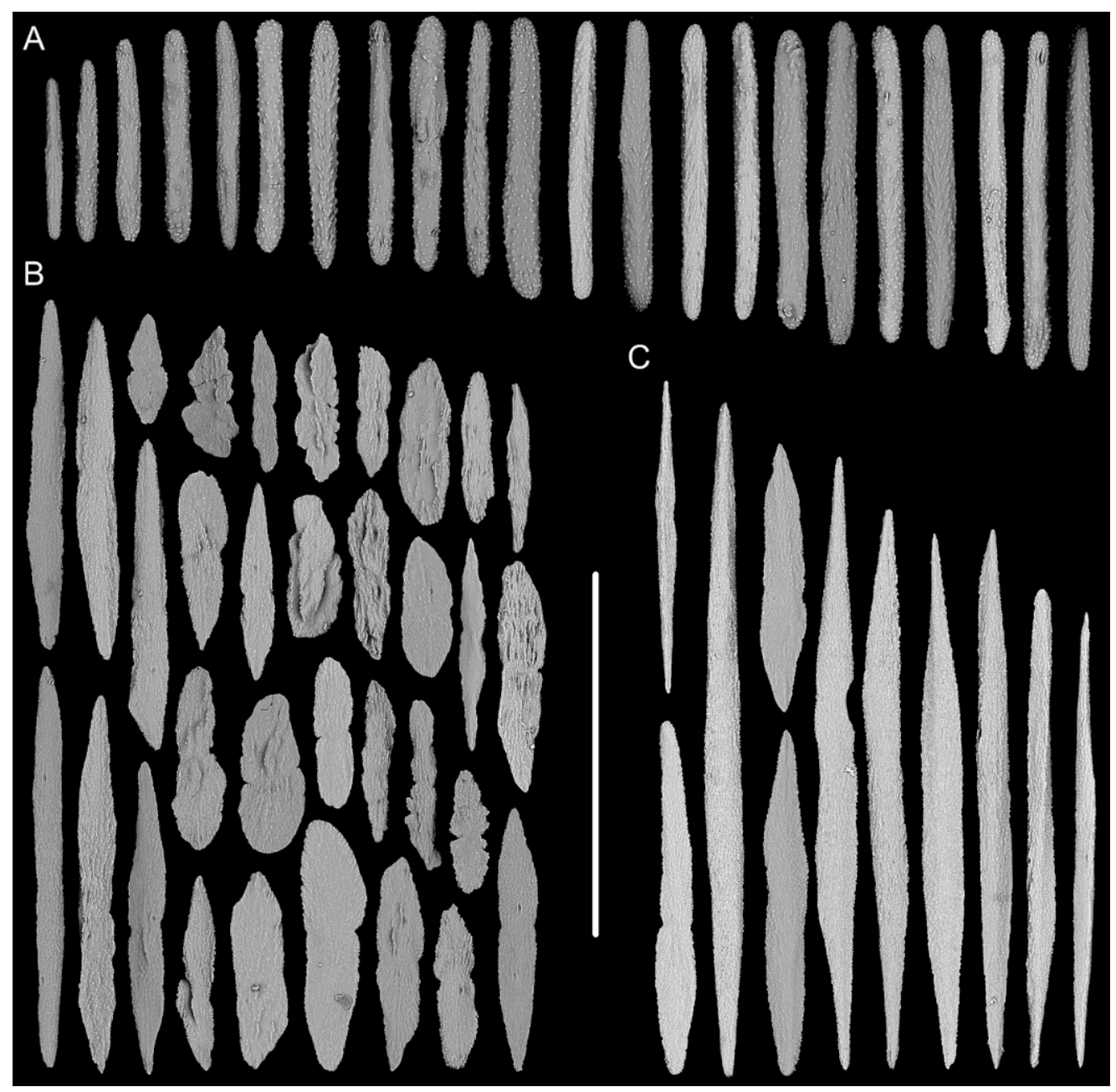

Figure 11. Sclerites of Iridogorgia densispicula Xu et al. 2020 specimen MBM286446. (A) Sclerites in tentacle rachis. (B) Sclerites in polyp body wall. (C) Sclerites in coenenchyme. Scales $=500 \mu \mathrm{m}$, all in the same scale. 
Distribution. Seamounts located on the Caroline Ridge, 1204-1741 m ([7]).

Remarks. Our specimens match well with the previous description, and they all have a slender stem, high helical turn, oblique polyps, and the same sclerite forms in tentacles and coenenchyme (Figures 9-13). Considering only one holotype described before, here we make a supplementary description for this species, especially the varied sclerites in the polyp body wall, including spindles and scales, which are elongated and often with irregular edges and rugged and ridged surfaces (Figures 11B, 12B and 13B). It is worth noting that the elongated scales are occasionally present in the tentacles of the specimen MBM286448 (Figure 13A). These special scales may be an extension from the body extending to the tentacles. Furthermore, the polyp shapes in these specimens are variable, including bud-like (holotype and MBM286448, Figure 10C), slender with elongate body (MBM286446, Figure 10A), cylindrical with long extended tentacles (MBM286447, Figure 10B). Such difference may be a process of growth stages (mature or immature) and caused by the alcohol preservation.

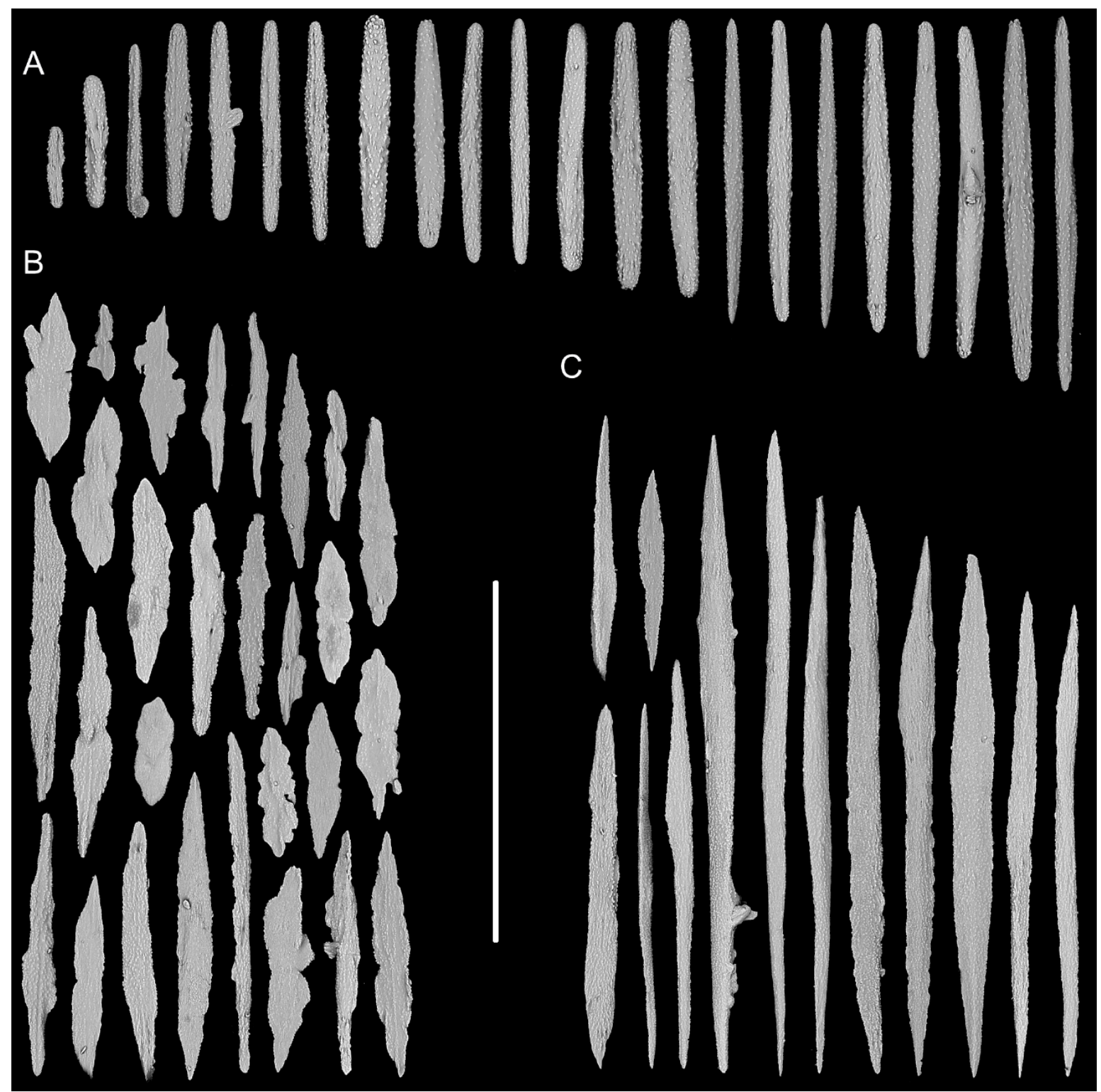

Figure 12. Sclerites of Iridogorgia densispicula Xu et al. 2020 specimen MBM286447. (A) Sclerites in tentacles. (B) Sclerites in polyp body wall. (C) Sclerites in coenenchyme. Scales $=500 \mu \mathrm{m}$, all in the same scale. 


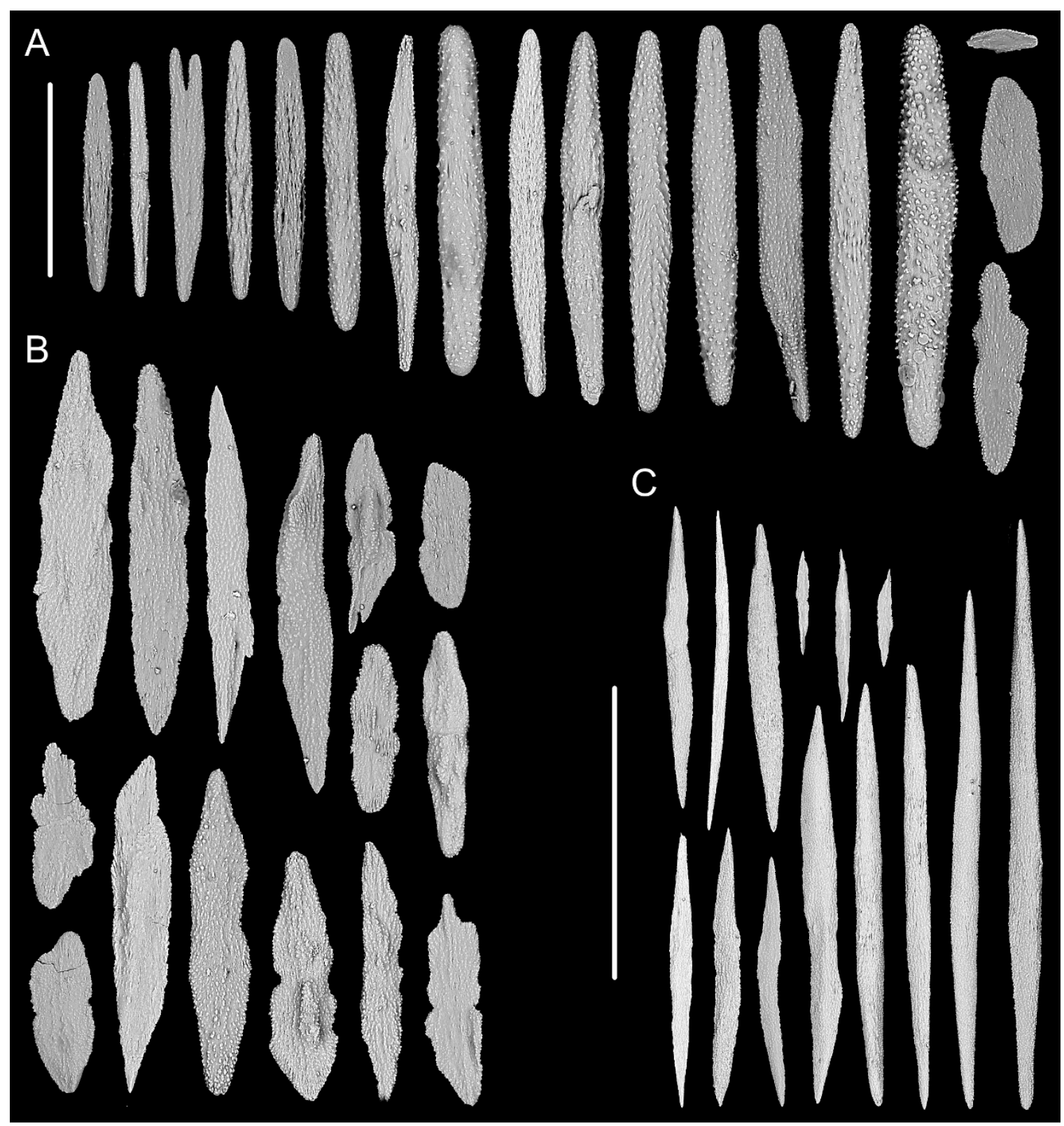

Figure 13. Sclerites of Iridogorgia densispicula Xu et al. 2020 specimen MBM286448. (A) Sclerites in tentacles. (B) Sclerites in polyp body wall. (C) Sclerites in coenenchyme. Scales $=200 \mu \mathrm{m}(\mathbf{A}, \mathbf{B}$ in the same scale), $500 \mu \mathrm{m}(\mathbf{C})$.

\subsection{Genetic Distance and Phylogenetic Analyses}

The new sequences were deposited in GenBank (Table 1). The alignments comprised 663, 537 and 797 nucleotide positions for the mtMutS, COI and 28S rDNA regions, respectively. Based on the aligned region of $28 \mathrm{~S}$ rDNA, the interspecific distance of Iridogorgia ranged from $0.32 \%$ to $6.08 \%$ (average value at $3.10 \%$ ), while the intraspecific distance was $0.32 \%$, which was calculated from only two populations of Iridogorgia magnispiralis (Table 3). For the concatenated region mtMutS-28S, the interspecific distance range is in the range of $0.31 \%-3.48 \%$, and no intraspecific data are available (Table 3). For the mitochondrial alignments, the interspecific and intraspecific distances of Iridogorgia are in ranges of $0-1.33 \%$ and $0-0.33 \%$ for mtMutS, and $0-0.39 \%$ and zero for COI, respectively (Tables 4 and 5 ). The genetic distances between Rhodaniridogorgia and Iridogorgia are in ranges of $0.47 \%-1.41 \%$ for $\mathrm{mtMutS}$, and $0-0.39 \%$ for COI, which partially and fully overlap with the interspecific distances of Iridogorgia, respectively (Tables 4 and 5). 
Table 3. Genetic distances at 28S rDNA (lower left) and the concatenated mtMutS -28S (upper right) of Iridogorgia species.

\begin{tabular}{|c|c|c|c|c|c|c|c|c|}
\hline & & 1 & 2 & 3 & 4 & 5 & 6 & 7 \\
\hline 1 & Iridogorgia densispiralis sp. nov. MW841043 & - & $1.17 \%$ & $0.31 \%$ & $3.48 \%$ & $1.64 \%$ & - & - \\
\hline 2 & Iridogorgia flexilis sp. nov. MW841041 & $2.30 \%$ & - & $1.09 \%$ & $2.76 \%$ & $0.46 \%$ & - & - \\
\hline 3 & Iridogorgia verrucosa sp. nov. MW841044 & $0.65 \%$ & $2.13 \%$ & - & $3.40 \%$ & $1.56 \%$ & - & - \\
\hline 5 & Iridogorgia magnispiralis MW841042 & $2.97 \%$ & $0.65 \%$ & $2.80 \%$ & $5.37 \%$ & - & - & - \\
\hline 6 & Iridogorgia magnispiralis KX890214 & $3.30 \%$ & $0.98 \%$ & $3.13 \%$ & $5.54 \%$ & $0.32 \%$ & - & - \\
\hline 7 & Iridogorgia splendens KX890215 & $0.32 \%$ & $2.30 \%$ & $0.98 \%$ & $5.72 \%$ & $2.97 \%$ & $3.30 \%$ & - \\
\hline
\end{tabular}

New sequences are in bold.

Table 4. Interspecific and intraspecific distances at mtMutS of Iridogorgia and Rhodaniridogorgia species.

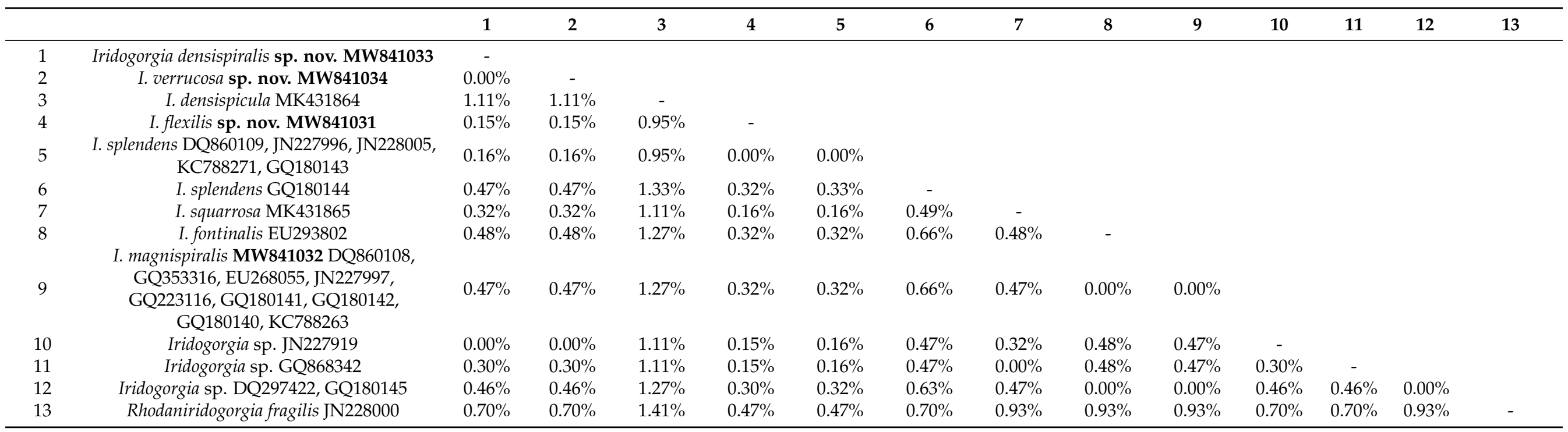

New sequences are in bold. 
Table 5. Interspecific and intraspecific distances at COI of Iridogorgia and Rhodaniridogorgia species.

\begin{tabular}{|c|c|c|c|c|c|c|c|c|c|c|}
\hline & & 1 & 2 & 3 & 4 & 5 & 6 & 7 & 8 & 9 \\
\hline 1 & Iridogorgia densispiralis sp. nov. MW841036 & - & & & & & & & & \\
\hline 2 & Iridogorgia verrucosa sp. nov. MW840138 & 0 & - & & & & & & & \\
\hline 3 & Iridogorgia flexilis sp. nov. MW841035 & 0 & 0 & - & & & & & & \\
\hline 5 & Iridogorgia sp. GQ868323 & 0 & 0 & 0 & 0 & - & & & & \\
\hline 6 & Iridogorgia densispicula MW841037 & $0.20 \%$ & $0.20 \%$ & $0.20 \%$ & $0.20 \%$ & $0.20 \%$ & - & & & \\
\hline 7 & Iridogorgia fontinalis GQ868321 & $0.19 \%$ & $0.19 \%$ & $0.19 \%$ & $0.19 \%$ & $0.19 \%$ & $0.39 \%$ & - & & \\
\hline 8 & $\begin{array}{c}\text { Iridogorgia magnispiralis MW841039, FJ268639, } \\
\text { GQ868318, KC788237 }\end{array}$ & $0.19 \%$ & $0.19 \%$ & $0.19 \%$ & $0.19 \%$ & $0.19 \%$ & $0.39 \%$ & 0 & 0 & \\
\hline 9 & Rhodaniridogorgia fragilis JN227954 & $0.20 \%$ & $0.20 \%$ & $0.20 \%$ & $0.20 \%$ & $0.20 \%$ & $0.39 \%$ & 0 & 0 & 0 \\
\hline
\end{tabular}


The ML tree is nearly identical to the BI tree in topology for both the mtMutS-COI and $28 \mathrm{~S}$ rDNA regions, and thus a single tree with both support values was shown for each of the markers (Figures 14 and 15). In the mtMutS-COI trees, the monophyly of Iridogorgia was not supported due to the Rhodaniridogorgia nested into the Iridogorgia clade, and clustered with the subclade of I. magnispiralis, I. fontinalis and Iridogorgia sp. GQ180145 with low to moderate support (Figure 14). Within Iridogorgia, Iridogorgia densispicula branched outside of the main clade including the rest of the Iridogorgia species. Like the subclade of magnispiralis/fontinali, I. densispiralis sp. nov., I. verrucosa sp. nov. and Iridogorgia sp. GQ868342 also formed a subclade due to no genetic variation among the them (Tables 4 and 5 and Figure 14). Although I. flexilis sp. nov., I. splendens, Iridogorgia sp. GQ868342 and the subclades magnispiralis / fontinalis and densispiralis /verrucosa branched together, their deeply divergent relationships were not resolved (Figure 14). In the $28 \mathrm{~S}$ rDNA trees, I. densispicula branched early, and the rest of the Iridogorgia species were separated to two clades with low support (ML < 70\%; BI < 0.90; Figure 15). Within Clade I, I. densispiralis sp. nov. and I. splendens branched together, followed by I. verrucosa sp. nov. with high support. Iridogorgia flexilis sp. nov. and I. magnispiralis formed the Clade II with high support.

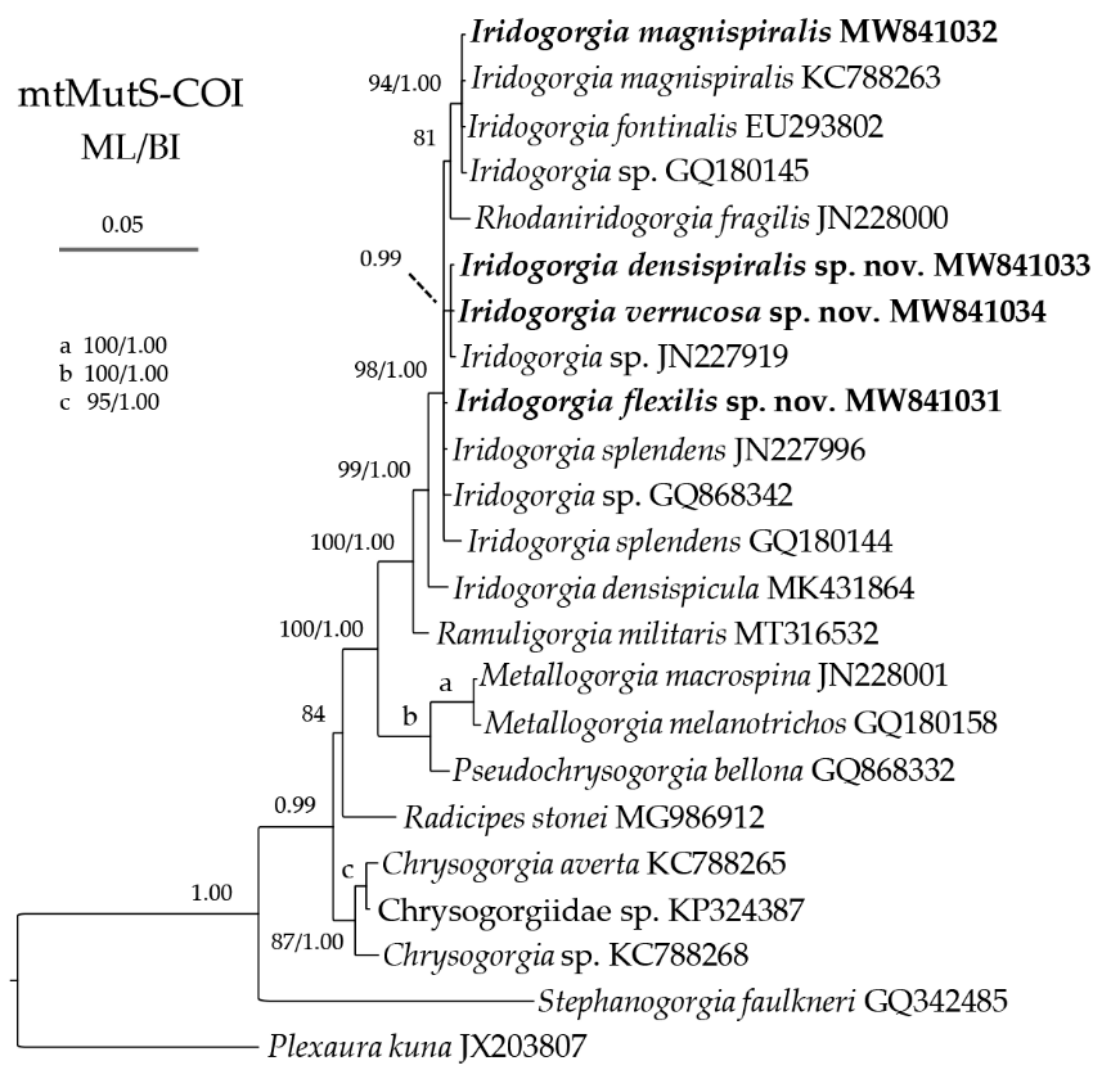

Figure 14. Bayesian inference (BI) tree constructed by the concatenated sequences of mtMutS and COI showing phylogenetic relationships among Iridogorgia and Rhodaniridogorgia species. The Maximum likelihood (ML) tree is identical to the BI tree in topology. Node support is as follows: ML bootstrap/BI posterior probability. The ML bootstrap $<70 \%$ or BI posterior probability $<0.90$ is not shown. Newly sequenced species are in bold. The GenBank accession numbers of the mtMutS sequences were listed next to the species names. 


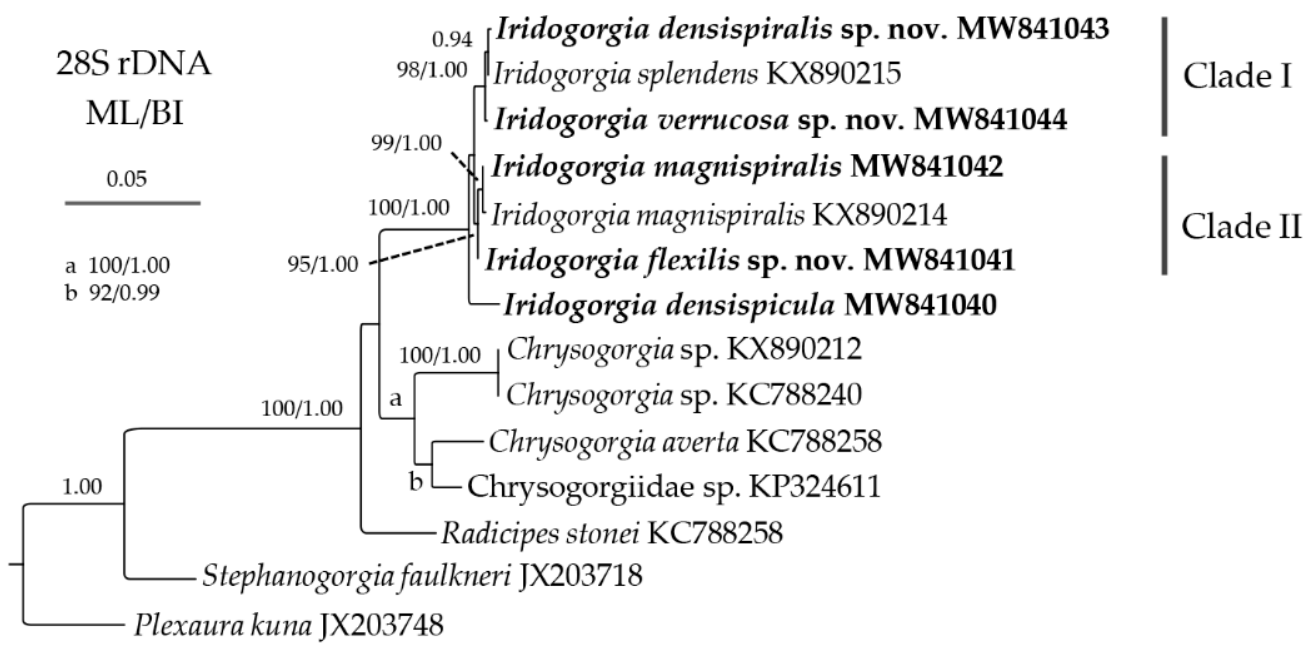

Figure 15. Maximum likelihood (ML) tree constructed by $28 \mathrm{~S}$ rDNA showing phylogenetic relationships among Iridogorgia species. The Bayesian inference (BI) tree is identical with the ML tree in topology. Node support is as follows: ML bootstrap/BI posterior probability. The ML bootstrap $<70 \%$ or BI posterior probability $<0.90$ is not shown. Newly sequenced species are in bold. The GenBank accession numbers of the $28 \mathrm{~S}$ rDNA sequences were listed next to the species names.

\section{Discussion}

The DNA barcoding analysis of mtMutS, COI and 28S rDNA is considered as one of the first steps in an integrative identification of octocorals [19,41,42]. In the present analysis, COI exhibited much less variation than the other two loci, and no genetic variability was observed among the three new species and I. splendens Watling, 2007 (Table 5). Consequently, COI is less informative as a species-specific marker for octocorals. For the mtMutS, there is no barcoding gap for delimitating Iridogorgia species due to no genetic variability observed between I. densispiralis sp. nov. and I. verrucosa sp. nov., and between I. fontinalis Watling, 2007 and I. magnispiralis Watling, 2007, indicating its limited usefulness for the species delimitation (Table 4). In contrast, the $28 \mathrm{~S}$ rDNA showed a higher level of genetic variation (e.g., interspecific distances $0.32-6.08 \%$ with average value of $3.10 \%$ vs. $0-1.33 \%$ at $\mathrm{mtMutS}$ and $0-0.39 \%$ at COI). A threshold of $0.5 \%$ can delimit all available Iridogorgia species except for I. splendens KX890215 (the distance between it and I. densispiralis sp. nov. is $0.32 \%$ ). Like the case of $28 \mathrm{~S}$ rDNA, the concatenated region mtMutS-28S can separate the present five species with a commonly used threshold of $0.3 \%$ (Table 3). Nonetheless, only seven Iridogorgia sequences of $28 \mathrm{~S}$ rDNA are available, more data including both conspecific and congeneric sequences are needed to confirm $28 \mathrm{~S}$ rDNA and mtMutS-28S as effective barcodes for the genus Iridogorgia.

The genus Rhodaniridogorgia was established by Watling [4] to contain the species Rhodaniridogorgia fragilis Walting, 2007 and R. superba (Nutting, 1908) transferred from Iridogorgia. It has a similar external shape and sclerites with Iridogorgia and is distinct mainly by the axis shape (wavy vs. coiled; [4]). In the mtMutS-COI trees, Rhodaniridogorgia fragilis nested into the Iridogorgia clade, and showed a close relationship with I. magnispiralis and I. fontinalis with low to moderate support, and the genetic distance data do not support the separation of R. fragilis from Iridogorgia (Tables 4 and 5; Figure 14). Furthermore, the wavy shape of the axis can be seen as a specific coiled spiral, when the helical diameter is narrow. Therefore, based on the morphological and phylogenetic data, we suggest a new combination Iridogorgia fragilis (Watling, 2007) comb. nov., resurrect I. superba Nutting, 1908 and eliminate the genus Rhodaniridogorgia. Here, we slightly update the diagnosed Iridogorgia to include the fragilis-like species: Chrysogorgiids with main axis monopodial, wavy or coiled spiraling upward, and undivided branches emanating from one side of the axis. Polyps uniserially arranged, when sexually mature with base expanded along upper side of branches. Sclerites rods, spindles, or scales, sometimes branched or with 
coarse sculptures. Branches coenenchyme with sclerites oriented along branches or without sclerites between polyps.

The present molecular phylogenetic analysis supported the assignment of the new species to the genus Iridogorgia. However, the mitochondrial marker MutS-COI could not resolve the deeply divergent relationships among the available Iridogorgia species except I. densispicula Xu, Zhan, Li and Xu, 2020 (Figure 14). In contrast, 28S rDNA showed better resolution for the Iridogorgia phylogeny. In the $28 \mathrm{~S}$ rDNA trees, I. densispiralis sp. nov. showed close relationships with I. splendens and I. verrucosa sp. nov. This is consistent with their morphological characters that all these species have a relatively short colony and close helical turn in adults with branches producing nearly from the bottom to top (Figures 3B, 5B and 15). Iridogorgia flexilis sp. nov. formed a sister clade with $I$. magnispiralis, which is also consistent with the morphological data that all have a high colony and loosely helical turn with branches producing on the upper part of the colony (Figures 1B, 7C and 15).

Now there are twelve species in the genus Iridogorgia, for their distributions see the Figure 16. Among these, six species were reported from the Western Pacific, including $I$. flexilis sp. nov., I. verrucosa sp. nov., I. densispiralis sp. nov., I. magnispiralis, I. densispicula and I. squarrosa $\mathrm{Xu}, \mathrm{Zhan}, \mathrm{Li}$ and $\mathrm{Xu}, 2020$. The data indicate a high diversity of Iridogorgia in Western Pacific and provide a potential reference for vulnerable marine ecosystems and seamount conservation.

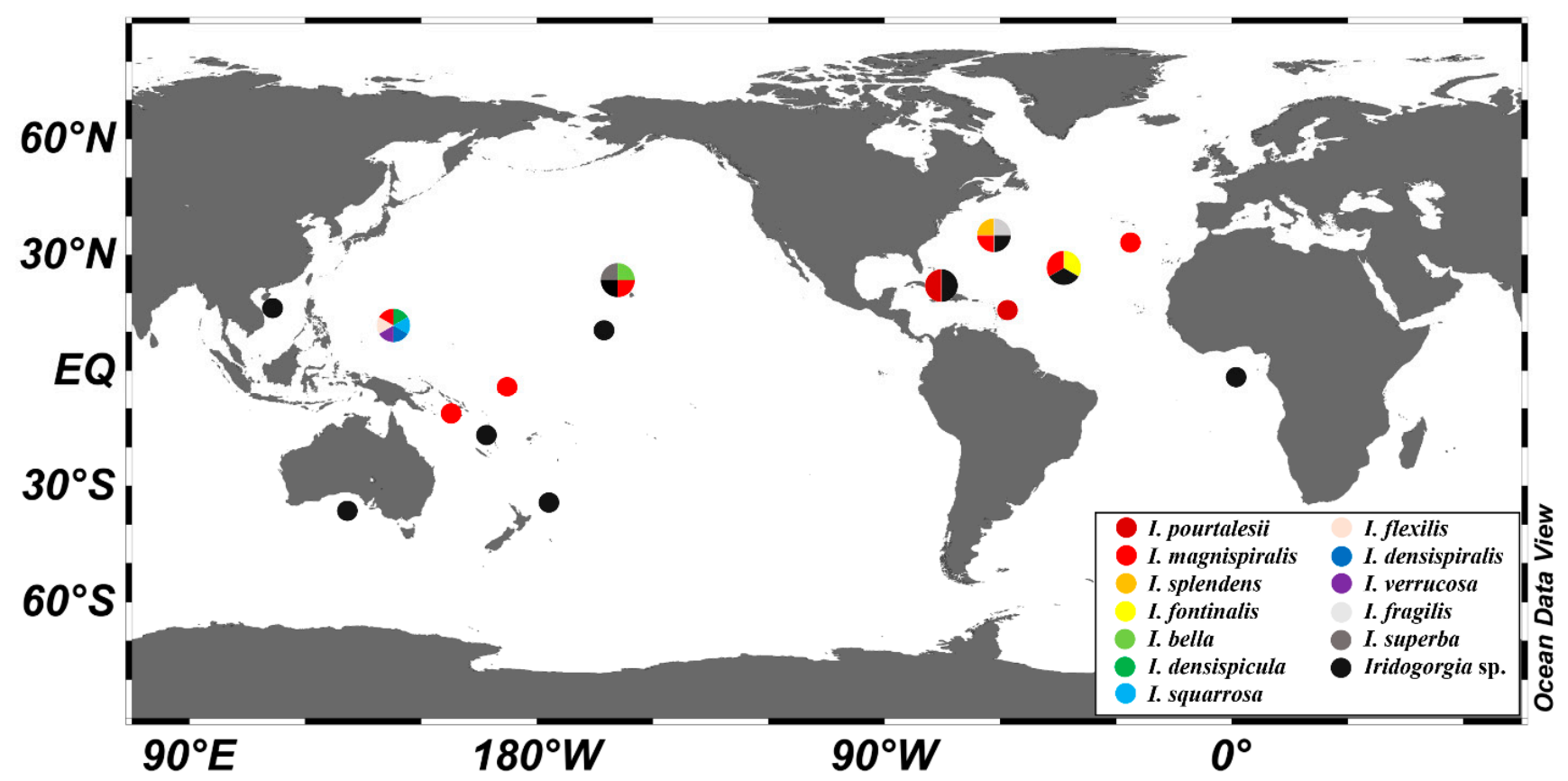

Figure 16. The distributions of the species of Iridogorgia, based on the data of references $[4-8,10-14,39,40,43]$.

In order to distinguish the Iridogorgia species better, a dichotomous key based on morphological features is given. Due to the incomplete holotype and vague original description, I. bella is temporarily not considered here. 
1. Colony with a wavy axis. .2

- Colony with a coiled axis .3

2. Sclerites with a wide range of shapes, including spindles and scales. I. fragilis

- Sclerites uniform in size and shape, including slender smooth rods. I. superba

3. Colony with loose helix in adult, each helical turn $\geq 12 \mathrm{~cm}$ high. .4

- Colony with close helix in adult, each helical turn $\leq 7 \mathrm{~cm}$ high...... 7

4. Scales present in the polyp body wall...................................................... 5

-Scales absent in the polyp body wall............................................. magnispiralis

5. Sclerites in the polyp body wall usually without large tuberculate warts; small lumpy sclerites absent.....

-Sclerites in the polyp body wall usually sculptured by numerous large tuberculate warts; small lumpy sclerites often present........................................... squarrosa

6. Sclerites in the polyp body wall relatively slender and thin, surface coarse and/or rugged..... I. densispicula - Sclerites in the polyp body wall stout and thick, surface relatively smooth. I. flexilis sp. nov.

7. Sclerites rare to absent in the inter-polyps coenenchyme.

- Sclerites sparse to numerous in the inter-polyps coenenchyme.

8. Scales present in polyps. I. splendens

- Scales absent in polyps.... I. pourtalesii

9. Branches producing on the top of colony (umbrella-shaped) I. fontinalis

- Branches producing from nearly bottom to top or the upper half of colony (tree-shaped)

10. Rods present in coenenchyme I. densispiralis sp. nov.

- Rods absent in coenenchyme. I. verrucosa sp. nov.

\section{Conclusions}

Based on an integrated morphological-molecular approach, eight sampled specimens of Iridogorgia from seamounts in the tropical Western Pacific are identified as three new species I. flexilis sp. nov., I. densispiralis sp. nov. and I. verrucosa sp. nov., and two known species I. magnispiralis Watling, 2007 and I. densispicula Xu, Zhan, Li and Xu, 2020. Phylogenetic analysis based on the nuclear $28 \mathrm{~S} \mathrm{rDNA}$, indicated that I. densispiralis sp. nov. showed close relationships with I. splendens Watling, 2007 and I. verrucosa sp. nov., and I. flexilis sp. nov. formed a sister clade with I. magnispiralis. The genetic analysis demonstrates that neither the mtMutS nor COI barcodes could resolve species boundaries adequately, while 28S rDNA showed potential application in DNA barcoding and phylogenetic reconstruction for this genus. In addition, based on morphological characters and the mitochondrial gene data, we propose to eliminate the genus Rhodaniridogorgia by establishing a new combination Iridogorgia fragilis (Watling, 2007) comb. nov. and resurrecting I. superba Nutting, 1908.

Author Contributions: The research was conceived and designed by K.X., Y.X. and Z.Z. Sampling conducted by K.X. Morphology was studied by Y.X. Molecular analysis was performed by Z.Z. All authors have read and agreed to the published version of the manuscript.

Funding: This research was funded by the Key Program of National Natural Science Foundation of China (No. 41930533), the Science \& Technology Basic Resources Investigation Program of China (2017FY100804), the Strategic Priority Research Program of Chinese Academy of Sciences (XDB42000000) and the Senior User Project of RV KEXUE (KEXUE2018G27, E12414101Q).

Institutional Review Board Statement: Not applicable.

Informed Consent Statement: Not applicable.

Data Availability Statement: The specimens described in this study are available at the Marine Biological Museum of Chinese Academy of Sciences (MBMCAS) at Institute of Oceanology, Qingdao, 
China. Voucher IDs: Iridogorgia flexilis sp. nov.: MBM286453; I. densispiralis sp. nov.: MBM286454; I. verrucosa sp. nov.: MBM286455; I. magnispiralis Watling, 2007: MBM286450, MBM286451; I. densispicula Xu, Zhan, Li \& Xu, 2020: MBM286446, MBM286447, MBM286448. The mtMuts sequences that support the findings of this study have been deposited in NCBI GenBank with the accession codes MW841031 (I. flexilis sp. nov.), MW841033 (I. densispiralis sp. nov.), MW841034 (I. verrucosa sp. nov.) and MW841032 (I. magnispiralis). The COI sequences that support the findings of this study have been deposited in NCBI GenBank with the accession codes MW841035 (I. flexilis sp. nov.), MW841036 (I. densispiralis sp. nov.), MW841038 (I. verrucosa sp. nov.), MW841039 (I. magnispiralis) and MW841037 (I. densispicula). The $28 \mathrm{~S}$ sequences that support the findings of this study have been deposited in NCBI GenBank with the accession codes MW841041 (I. flexilis sp. nov.), MW841043 (I. densispiralis sp. nov.), MW841044 (I. verrucosa sp. nov.), MW841042 (I. magnispiralis) and MW841040 (I. densispicula). The new species registration of Iridogorgia flexilis sp. nov., I. densispiralis sp. nov. and I. verrucosa sp. nov. in Zoobank with LSID: urn:lsid:zoobank.org:act:6BD2C9FC-9CD84604-971D-B2EC0BB108B8, urn:lsid:zoobank.org:act:026E2F14-7A66-4558-9D65-B7E3CC0EC8D0 and urn:lsid:zoobank.org:act:E388B7B2-936E-485C-AB38-E7F95DD4F0A4, respectively. The publication LSID: urn:lsid:zoobank.org:pub:273D89B3-0E5C-42C7-9EF7-4526330B92B1.

Acknowledgments: We thank the assistance of the crew of R/V KeXue and ROV FaXian for sample collection. Special thanks go to Shaoqing Wang for taking the photos on board.

Conflicts of Interest: The authors declare no conflict of interest.

\section{References}

1. Roberts, J.M.; Wheeler, A.J.; Freiwald, A.; Cairns, S.D. Cold-Water Corals: The Biology and Geology of Deep-Sea Coral Habitats; Cambridge University Press: Cambridge, UK, 2009; pp. 1-368.

2. Dautova, T.N. Octocorallia as a key taxon in the vulnerable marine ecosystems of the Emperor Chain (Northwest Pacific): Diversity, distribution and biogeographical boundary. In Marine Biodiversity for a Healthy Ocean-Biodiversity, Functional Groups and Ocean Health, Proceedings of the Russia-China Bilateral Workshop, Vladivostok, Russia, 10-11 October 2019; Lutaenko, K.A., Ed.; Publishing House of the Far Eastern Federal University: Vladivostok, Russia, 2019; pp. 68-80.

3. Pérez, C.D.; de Moura Neves, B.; Cordeiro, R.T.S.; Williams, G.C.; Cairns, S.D. Diversity and distribution of Octocorallia. In The Cnidaria, Past, Present and Future; Goffredo, S., Dubinsky, Z., Eds.; Springer: Cham, Switzerland, 2016; pp. 109-123. [CrossRef]

4. Watling, L. A review of the genus Iridogorgia (Octocorallia: Chrysogorgiidae) and its relatives, chiefly from the North Atlantic Ocean. J. Mar. Biol. Assoc. UK 2007, 87, 393-402. [CrossRef]

5. Watling, L.; France, S.C.; Pante, E.; Simpson, A. Biology of deep-water octocorals. In Advances in Marine Biology; Lesser, M., Ed.; Elsevier Academic Press: Burlington, NJ, USA, 2011; pp. 41-122.

6. Pante, E.; France, S.C.; Couloux, A.; Cruaud, C.; McFadden, C.S.; Samadi, S.; Watling, L. Deep-sea origin and in-situ diversification of chrysogorgiid octocorals. PLoS ONE 2012, 7, e38357. [CrossRef]

7. Xu, Y.; Zhan, Z.; Li, Y.; Xu, K. Morphology and phylogenetic analysis of two new species of deep-sea golden gorgonians (Cnidaria: Octocorallia: Chrysogorgiidae) from seamounts in the Western Pacific Ocean. Zootaxa 2020, 4731, 249-262. [CrossRef]

8. Watling, L.; Rowley, S.; Guinotte, J. The world's largest known gorgonian. Zootaxa 2013, 3630, 198-199. [CrossRef]

9. Cordeiro, R.; McFadden, C.; van Ofwegen, L.; Williams, G. World List of Octocorallia. Iridogorgia Verrill. 1883. World Register of Marine Species. Available online: http:/ / www.marinespecies.org/aphia.php? p=taxdetails\&id=125295 (accessed on 10 June 2021).

10. Verrill, A.E. Report on the Anthozoa, and on some additional species dredged by the "Blake" in 1877-1879, and by the U.S. Fish Commission steamer "Fish Hawk" in 1880-1882. Bull. Mus. Comp. Zool. Harv. Coll. 1883, 11, 1-72.

11. Cairns, S.D.; Hourigan, T.F. A Comprehensive List of Known Deep-Sea Corals Occurring in the EEZ of the United States and its Possessions. 2017. Available online: https:/ / deepseacoraldata.noaa.gov/ (accessed on 28 April 2021).

12. Nutting, C.C. Descriptions of the Alcyonaria collected by the U.S. Bureau of Fisheries steamer Albatross in the vicinity of the Hawaiian Islands in 1902. Proc. U.S. Nat. Mus. 1908, 34, 543-601. [CrossRef]

13. Parrish, F.A.; Baco-Tayor, A.R.; Kelley, C.; Cairns, S.D.; Hourigan, T.F. Deep-Sea Coral Taxa in the Hawaiian Archipelago and other U.S. Pacific Islands: Depth and Geographical Distribution. 2017. Available online: https://deepseacoraldata.noaa.gov / (accessed on 28 April 2021).

14. Auscavitch, S.R.; Deere, M.C.; Keller, A.G.; Rotjan, R.D.; Shank, T.M.; Cordes, E.E. Oceanographic Drivers of Deep-Sea Coral Species Distribution and Community Assembly on Seamounts, Islands, Atolls, and Reefs Within the Phoenix Islands Protected Area. Front. Mar. Sci. 2020, 7, 42. [CrossRef]

15. Bayer, F.M.; Grasshoff, M.; Verseveldt, J. Illustrated Trilingual Glossary of Morphological and Anatomical Terms Applied to Octocorallia; E. J. Brill Publishers: Leiden, The Netherlands, 1983; p. 75.

16. Herrera, S.; Baco, A.; Sánchez, J.A. Molecular systematics of the bubblegum coral genera (Paragorgiidae, Octocorallia) and description of a new deep-sea species. Mol. Phylogenet. Evol. 2010, 55, 123-135. [CrossRef] 
17. Sánchez, J.A.; Lasker, H.R.; Taylor, D.J. Phylogenetic analyses among octocorals (Cnidaria): Mitochondrial and nuclear DNA sequences (lsu-rRNA, 16S and ssu-rRNA, 18S) support two convergent clades of branching gorgonians. Mol. Biol. Evol. 2003, 29, 31-42. [CrossRef]

18. Folmer, O.; Black, M.; Hoeh, W.; Lutz, R.; Vrijenhoek, R. DNA primers for amplification of mitochondrial cytochrome coxidase subunit I from diverse metazoan invertebrates. Mol. Mar. Biol. Biotech. 1994, 3, 294-299.

19. McFadden, C.S.; van Ofwegen, L.P. A second, cryptic species of the soft coral genus Incrustatus (Anthozoa: Octocorallia: Clavulariidae) from Tierra del Fuego, Argentina revealed by DNA barcoding. Helgol. Mar. Res. 2013, 67, 137-147. [CrossRef]

20. Katoh, K.; Standley, D.M. MAFFT Multiple Sequence Alignment Software version 7: Improvements in performance and usability. Mol. Biol. Evol. 2013, 30, 772-780. [CrossRef]

21. Hall, T.A. BioEdit: A user-friendly biological sequence alignment editor and analysis program for Windows 95/98/NT. Nucl. Acids Sym. Ser. 1999, 41, 95-98.

22. Tamura, K.; Stecher, G.; Peterson, D.; Filipski, A.; Kumar, S. MEGA6: Molecular Evolutionary Genetics Analysis Version 6.0. Mol. Biol. Evol. 2013, 30, 2725-2729. [CrossRef] [PubMed]

23. Guindon, S.; Dufayard, J.F.; Lefort, V.; Anisimova, M.; Hordijk, W.; Gascuel, O. New algorithms and methods to estimate maximum-likelihood phylogenies: Assessing the performance of PhyML 3.0. Syst. Biol. 2010, 59, 307-321. [CrossRef]

24. Hillis, D.M.; Bull, J.J. An empirical test of bootstrapping as a method for assessing confidence in phylogenetic analysis. Syst. Biol. 1993, 42, 182-192. [CrossRef]

25. Ronquist, F.R.; Huelsenbeck, J.P. Mrbayes 3: Bayesian phylogenetic inference under mixed models. Bioinformatics 2003, 19, 1572-1574. [CrossRef]

26. Rambaut, A.; Drummond, A.J. Tracer v1.4. Available online: http://beast.bio.ed.ac.uk/Tracer (accessed on 28 April 2021).

27. Alfaro, M.E.; Zoller, S.; Lutzoni, F. Bayes or Bootstrap? A simulation study comparing the performance of Bayesian Markov chain Monte Carlo sampling and bootstrapping in assessing phylogenetic confidence. Mol. Biol. Evol. 2003, 20, 255-266. [CrossRef] [PubMed]

28. Quattrini, A.M.; Georgian, S.E.; Byrnes, L.; Stevens, A.; Falco, R.; Cordes, E.E. Niche divergence by deep-sea octocorals in the genus Callogorgia across the continental slope of the Gulf of Mexico. Mol. Ecol. 2013, 22, 4123-4140. [CrossRef]

29. Quattrini, A.M.; Gómez, C.E.; Cordes, E.E. Environmental filtering and neutral processes shape octocoral community assembly in the deep sea. Oecologia 2017, 183, 221-236. [CrossRef]

30. Thoma, J.N.; Pante, E.; Brugler, M.R.; France, S.C. Deep-sea octocorals and antipatharians show no evidence of seamount-scale endemism in the NW Atlantic. Mar. Ecol. Prog. Ser. 2009, 397, 25-35. [CrossRef]

31. Song, X.; Lyu, M.; Zhang, X.; Ruthensteiner, B.; Ahn, I.-Y.; Pastorino, G.; Wang, Y.; Gu, Y.; Ta, K.; Sun, J.; et al. Large plastic debris dumps: New biodiversity hot spots emerging on the deep-sea floor. Environ. Sci. Technol. Lett. 2021, 8, 148-154. [CrossRef]

32. Cairns, S.D.; Wirshing, H.H. A phylogenetic analysis of the Primnoidae (Anthozoa: Octocorallia: Calcaxonia) with analyses of character evolution and a key to the genera and subgenera. BMC Evol. Biol. 2018, 18, 1-20. [CrossRef]

33. Taylor, M.L.; Rogers, A.D. Evolutionary dynamics of a common sub-Antarctic octocoral family. Mol. Phylogenet. Evol. 2014, 84, 185-204. [CrossRef]

34. McFadden, C.S.; van Ofwegen, L.P. Stoloniferous octocorals (Anthozoa, Octocorallia) from South Africa, with descriptions of a new family of Alcyonacea, a new genus of Clavulariidae, and a new species of Cornularia (Cornulariidae). Invertebr. Syst. 2012, 26, 331-356. [CrossRef]

35. Ehrenberg, C.G. Beiträge zur physiologischen Kenntniss der Corallenthiere im allgemeinen, und besonders des rothen Meeres, nebst einem Versuche zur physiologischen Systematik derselben. Abh. Königlichen Akad. Wiss. Berl. 1834, 1, $225-380$.

36. Haeckel, E. Generelle Morphologie der Organismen; Verlag von Georg Reimer: Berlin, Germany, 1866; Volume 2, p. 652. [CrossRef]

37. Lamouroux, J.V.F. Extrait d'un mémoire sur la classification des polypiers coralligènes non entièrement piérreux. Nouv. Bull. Sci. Société Philomath. Paris 1812, 3, 181-188.

38. Grasshoff, M. The shallow-water gorgonians of New Caledonia and adjacent islands (Coelenterata, Octocorallia). Senckenbergiana Biol. 1999, 78, 1-121.

39. MacIntosh, H.; Althaus, F.; Williams, A.; Tanner, J.E.; Alderslade, P.; Ahyong, S.T.; Bax, N.; Criscione, F.; Crowther, A.L.; Farrelly, C.A.; et al. Invertebrate diversity in the deep Great Australian Bight (200-5000 m). Mar. Biodivers. Rec. 2018, 11, 23. [CrossRef]

40. Cairns, S.D.; Gerhswin, L.A.; Brook, F.; Pugh, P.R.; Dawson, E.W.; Ocaña, V.O.; Vervoort, W.; Williams, G.; Watson, J.; Opresko, D.M.; et al. Phylum Cnidaria: Corals, medusae, hydroids, myxozoans. In New Zealand Inventory of Biodiversity: Volume 1. Kingdom Animalia: Radiata, Lophotrochozoa, Deuterostomia; Gordon, D.P., Ed.; Canterbury University Press: Christchurch, New Zealand, 2009; p. 566.

41. McFadden, C.S.; Benayahu, Y.; Pante, E.; Thoma, J.N.; Nevarez, P.A.; France, S.C. Limitations of mitochondrial gene barcoding in Octocorallia. Mol. Ecol. Res. 2011, 11, 19-31. [CrossRef]

42. McFadden, C.S.; Brown, A.S.; Brayton, C.; Hunt, C.B.; van Ofwegen, L.P. Application of DNA barcoding in biodiversity studies of shallow-water octocorals: Molecular proxies agree with morphological estimates of species richness in Palau. Coral Reefs 2014, 33, 275-286. [CrossRef]

43. Dong, D.; Li, X.; Yang, M.; Gong, L.; Li, Y.; Sui, J.; Gan, Z.; Kou, Q.; Xiao, N.; Zhang, J. Report of epibenthic macrofauna found from Haima cold seeps and adjacent deep-sea habitats, South China Sea. Mar. Life Sci. Technol. 2020, 3, 1-2. [CrossRef] 